University of Louisville

ThinkIR: The University of Louisville's Institutional Repository

$5-2012$

\title{
'Rainbow nation' or 'Rambo nation'? : a comparative literary analysis of thematic changes in pre- and post- 1994 Black township novels.
}

D. A. Gantt 1986-

University of Louisville

Follow this and additional works at: https://ir.library.louisville.edu/etd

\section{Recommended Citation}

Gantt, D. A. 1986-, "'Rainbow nation' or 'Rambo nation'? : a comparative literary analysis of thematic changes in pre- and post- 1994 Black township novels." (2012). Electronic Theses and Dissertations. Paper 478.

https://doi.org/10.18297/etd/478

This Master's Thesis is brought to you for free and open access by ThinkIR: The University of Louisville's Institutional Repository. It has been accepted for inclusion in Electronic Theses and Dissertations by an authorized administrator of ThinkIR: The University of Louisville's Institutional Repository. This title appears here courtesy of the author, who has retained all other copyrights. For more information, please contact thinkir@louisville.edu. 


\title{
'RAINBOW NATION' OR 'RAMBO NATION'?: A COMPARATIVE LITERARY ANALYSIS OF THEMATIC CHANGES IN PRE- AND POST- 1994 BLACK TOWNSHIP NOVELS
}

By

\author{
D. A. Gantt \\ B.A., Vanderbilt University, 2009 \\ A Thesis \\ Submitted to the Faculty of the \\ College of Arts and Sciences of the University of Louisville \\ in Partial Fulfillment of the Requirements \\ for the Degree of
}

Master of Arts

Department of Pan-African Studies

University of Louisville

Louisville, Kentucky

May 2012 

TOWNSHIP NOVELS

\section{By}

Danielle Arianna Gantt

B.A., Vanderbilt University, 2009

A Thesis Approved on

April 17, 2012

by the following Thesis Committee:

\begin{tabular}{c}
\hline Esi Bani \\
Thesis Director \\
\hline Ricky Jones \\
\hline Elizabeth Willey
\end{tabular}




\section{ACKNOWLEDGEMENTS}

I would like to thank all of my committee members, Dr. Esi Bani, Dr. Ricky Jones, and Dr. Elizabeth Willey, for all of their guidance during this process and for helping me become a better scholar. I would also like to thank Dean J. Blaine Hudson and Bani Hines-Hudson for their encouragement and mentorship. Many thanks to my entire family, particularly my mother, Angela Strickland for her unwavering support. I would also like to express my deepest appreciation to David Hudgins for his patience and love. I would like to say thanks to my cohort and friends for helping me relax. 
ABSTRACT

\title{
'RAINBOW NATION' OR 'RAMBO NATION'?: A COMPARATIVE LITERARY ANALYSIS OF THEMATIC CHANGES IN PRE- AND POST- 1994 BLACK TOWNSHIP NOVELS
}

\author{
D. A. Gantt
}

April 17, 2012

Through content analysis of Ezekiel Mphahlele's Down Second Avenue, Modikwe Dikobe's The Marabi Dance, Zakes Mda's The Madonna of Excelsior, and Niq Mhlongo's After Tears, this study compares the themes of pre- and post1994 South African township novels using a post-colonial theoretical framework to determine how the tradition of Black protest literature has changed since the formal ending of Apartheid in 1994. The study finds that the pre-1994 Black writing tradition of critiquing poverty, corruption, and sexism is continued by Black writers in the post-1994 era. Thus, the findings in this study reveal that South Africa's title of "Rainbow Nation," while projecting South Africa as racially progressive, neglects the other forms of oppression in the country that Black writers continue to discuss in their works. The Black South African novels of post1994 also refute the "Rambo Nation" title, with the authors refusing to romanticize the Apartheid struggle. 


\section{TABLE OF CONTENTS}

\section{PAGE}

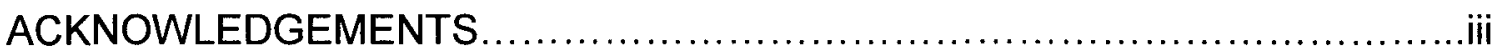

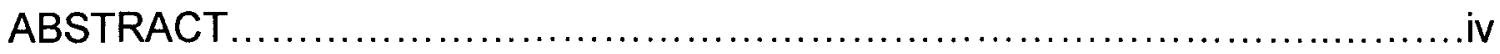

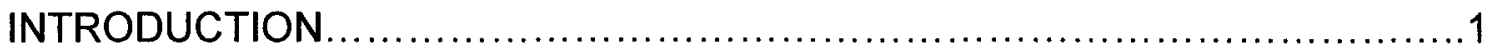

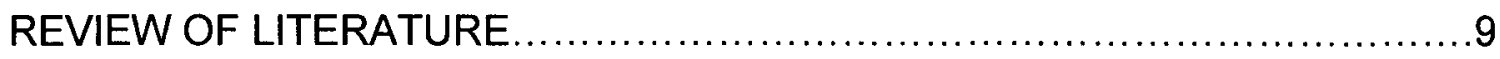

PRE-1994 | DOWN SECOND AVENUE .........................................14

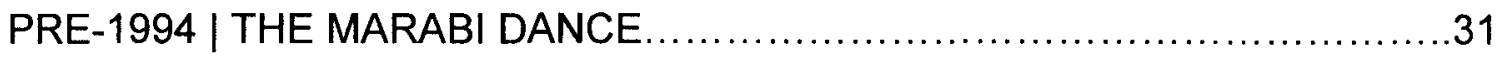

POST-1994 | THE MADONNA OF EXCELSIOR ................................51

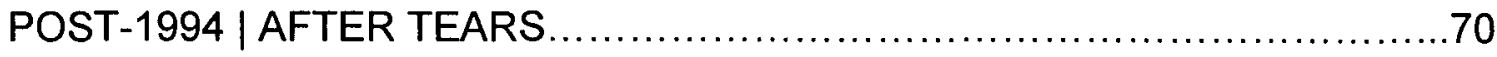

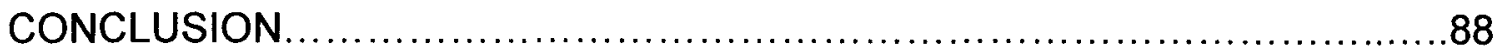

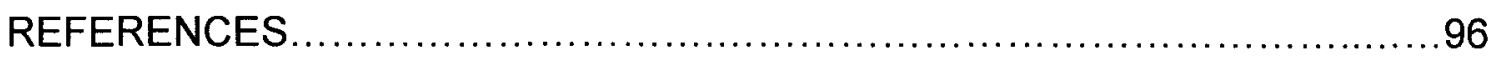

CURRICULUM VITAE ........................................................ 


\section{CHAPTER I}

\section{INTRODUCTION}

While implementation of Apartheid, the system of legal racial segregation in South Africa, officially began in 1948 , most scholars agree that the White supremacist philosophies and ideologies that formed Apartheid began much earlier than that. In fact, in 1797 , one hundred and fifty years before formal Apartheid was finalized, ordinances were implemented that excluded all natives from Southern Africa without "a pass" from their employers. Under Apartheid, however, these previous provisions took on a slew of new restrictions for nonWhite South Africans that ranged from a ban on mixed marriages to forced segregation in residential and all public areas. As act after act was passed, Apartheid began to define life in South Africa. Peter Nazareth states, "Apartheid affects every aspect of a person's life like a virulent form of cancer" (Nazareth 22).

One of the most potent weapons against Apartheid was literature, which could not escape the cancerous effects of Apartheid, because, as Piniel Shava explains, "Literature neither emerges from nor operates in a vacuum but that, whatever method it employs, the outcome is a close relationship between 
literature and the society of which it is a product" (Shava 1). Writer Ngũgĩ wa

Thiong'o believes,

.... Literature cannot escape from the class power structures that shape our everyday life. Here a writer has no choice. Whether or not he is aware of it, his works reflect one of more aspects of the intense economic, political, cultural and ideological struggles in a society... Every writer is a writer in politics (Thiong'o xii).

A system such as Apartheid, in which every part of one's life is under assault, demanded what Rosemary Jolly and Derek Attridge called "strategic opposition" (2 Writing South Africa).

In the twentieth century, literature played a large role in that "strategic opposition." The urgency of the struggle against Apartheid, as André Brink suggests, "produced a sense of priorities which made it very difficult for writerseven for writers who refused to be explicitly harnessed to any 'cause'-to write about certain very ordinary human situations (like a love relationship without direct political connotations) without inviting accusations of fiddling while Rome burns, of suppressing more 'urgent' issues, of avoiding 'reality,' or of selfindulgence" (Writing South Africa 15). This phenomenon was particularly strong for South Africa's non-White writers. Nazareth states, "Many South African writers (and, I would say, nearly all Black and 'Coloured' South African writers) are concerned with fighting Apartheid, with demonstrating how monstrous Apartheid is, with showing how it dehumanizes everybody" (Nazareth 22). Because of Apartheid, as Shava proclaims, "Black South African literature was a literature of protest" (Shava 1). The unjust system imposed on Black South 
African writers the need to report what was happening around them and to use their writings as a tool against oppression.

But, it is now 2012, eighteen years since anti-Apartheid activist Nelson Mandela was voted President of South Africa in the first multi-racial democratic elections in 1994. During a speech in 1989, anti-Apartheid activist and the first Black Archbishop of Cape Town Desmond Tutu borrowed from American activist Jesse Jackson's phrase "rainbow coalition" (who had himself borrowed the phrase from Black Panther Fred Hampton) and referred to the people of South Africa as "the rainbow children of God" (Boonzaier 100). The phrase stuck, and South Africa began to promote itself as the "Rainbow Nation." The locution was even used by President Mandela in his inauguration speech. South Africans, who were worn out after so many years of being embroiled in an undeclared civil war, latched onto the phrase. John Boonzaier proclaims, "It is a beautiful expression and one that paints a mental picture of people of different races and cultures living and working together in peace, love and harmony" (Boonzaier 100).

However, under its new title of "Rainbow Nation," something seems amiss. Jolly and Attridge express the "parodic effects" of the phrase "Rainbow Nation" when describing an interview between their colleague and a fifth grade student. Jolly and Attridge write,

When asked in a questionnaire, 'What would you teach American pupils about South African history?' the boy responded: 'I would tell them that we have a Rambo Nation.' [The symbolic] facet of the new South Africa is an encouraging one: the entity that has come into being is far too contradictory to be held up as a symbol of triumph that renders critical vigilance, including self-awareness, 
redundant. The New South Africa-the Rainbow Nation-is always on the verge of becoming the Rambo Nation (Writing South Africa $5)$.

"Rambo Nation" refers to the American film "First Blood," in which an exVietnam soldier, Rambo, played by Sylvester Stallone, goes on a violent rampage in an effort to escape from sheriffs who want to kill him. Thus, the film "First Blood" represents attempts of filmmakers to try to create a heroic Vietnam story where, in reality, there was none. Have post-1994 Black writers began to romanticize the Apartheid history now that Apartheid is formally over? Clearly, the violent plot of the "Rambo Nation" motif is in direct opposition to the fluffy, inspirational image of the "Rainbow Nation" and suggests that the symbolism of South Africa as a new country may be rooted in a contradictory reality. Also, the "Rambo Nation" gaff represents what Jolly and Attridge see as the danger of a romanticized South African history. In all of this nationalistic confusion, one must wonder what has happened to Black South African literature whose former "bread and butter" was the struggles of the Apartheid era. Now that Apartheid has formally ended, have Black South African writers abandoned their protests in favor of other types of writing? Has their writing been influenced by the proponents of hand-holding multiculturalism? Have they begun to re-write the history?

My thesis will analyze and compare Pre- and Post- 1994 South African township novels written by Black South African authors. Through analysis of Ezekiel Mphahlele's Down Second Avenue, Modikwe Dikobe's The Marabi Dance, Zakes Mda's The Madonna of Excelsior, and Niq Mhlongo's After Tears, 
my thesis seeks to understand how Black South African writers have perceived and currently perceive life in predominately Black townships. I hypothesize that the official ending of Apartheid and the symbolism of "The New South Africa," has now limited Black South African literature's critique of racism in the country, racism being an aspect of Apartheid life that they focused on in pre-1994 literature. The central objective of this study is to understand how South Africans are defining social change in their society. What have South Africans seen change in their country since Apartheid ended, and how does this change compare with the "Rainbow Nation" image that has been popularly projected. Authors have their own agendas and anything they write must, of course, be cautiously received. The South Africa that I am investigating is one that may be a place that all four authors have imagined. However, the tradition of protest literature is extremely strong in South Africa; to be a South African Black writer arguably means to take on the responsible of an accurate portrayal of South Africa. Consequently, my thesis has added significance for me, because I would like to use its findings to guide a future ethnographic research that will survey Black South Africans living in the Kayamandi township of Stellenbosch, South Africa, a Black settlement that I became familiar with in 2008 while studying abroad.

The novels that I have chosen to analyze have been chosen for various reasons. When Mphahlele wrote Down Second Avenue, he was in voluntary exile and had time to reflect. He suggested that the urgency from the "ever-present stimulus" of Apartheid, which had previously beckoned him and other writers to 
write prose, plays and other shorter works, had lessened (Mphahlele xxi). I feel that novels are less reactionary than, for example, newspaper articles or short literary pieces. I think the reflection required for novels makes them a good indicator of what writers want their audience to think. Also, I chose novels written of the English language tradition, because English represents "the body of literature that South African culture engages most fully with an international audience" (Writing South Africa 5). Additionally, the two Pre- 1994 novels are both considered canonical South African texts, while the two Post- 1994 novels are written by two celebrated and well known writers, Zakes Mda, who has won many South African literary awards for his works and Niq Mhlongo, who is considered one of the best writers among the latest crop of Black South African writers that has emerged (Dondio 1). In addition, the novels chosen span a considerable time period, with Down Second Avenue being first published in 1959, and After Tears being published in 2007. My thesis will analyze the texts in chronological order based on year of first publication, because this is a study of changing view over time, and a chronologic order will make this study organized as well as possibly revealing trends. I chose novels that were set in townships not only because that is where my future project will take place, but also because I believe that South African townships are the despair and yet the heart of Black South African life. Nkosi explains,

...the African township represented the strength and the will to survive by ordinary masses of the African people. In its own quiet way the township presented a dogged defiance against official persecution, for in the township the moments of splendor were very splendid indeed, surpassing anything White Johannesburg could offer (Nkosi 103). 
While many White authors have successfully written about township life, I felt that internationally, Black South African fiction writers have not received the same amount of exposure as their White counterparts, such as Nadine Gordimer and J. M. Coetzee. I also did not use any novels written by Colored authors, the mixed-race South African group who also was oppressed under the Apartheid system, because of the uncertainty and politics between Coloreds and Blacks. Also, I realize that none of my novels were written by women. This was not by choice, but rather because I was unable to find a work about township life by Black South African women writers. As Brink explains, South African women, Black and White, are "largely excluded from South African discourses" (Writing South Africa 23). Dennis Walder agrees, writing, "Apartheid may be gone, but as I write, despite the proposed liberalization of the new constitution, African women remained marginalized 'minors'..." (Writing South Africa 216). The slogan "Rainbow Nation" itself emphasizes race and ignores the issues of patriarchy and sexism (as well as other issues). Even though none of the novels chosen are written by women, The Marabi Dance and The Madonna of Excelsior both feature main characters who are women, which will offer the opportunity to explore how male writers write about women.

I will examine each novel using the qualitative research method. This method works best for my thesis because it seeks to answer questions and explore topics from "the perspectives of the local population it involves" (Guest et al. 1). I will consider the categories of character, structure/plot, setting, language, symbols, point of view, and character relationships, however my main focus will 
be on the themes in the novels, particularly how the authors treat the themes of racism, the relationship between Black and other non-White populations, gender roles, traditions, religion, and education. My study will use a post-colonial theoretical framework. I will read my texts under post-colonial theoretical assumption that the authors desire to contest the power of their oppressors. Bill Ashcroft et al. write

\begin{abstract}
Post-colonial societies were never simple 'culturally' controlled, because culture went hand in hand with political, economic and military domination. But imperial culture, and literature in particular, had a specially important function in enabling comparatively small occupying forces to exert hegemonic control over large populations. For this very reason, it became a site of resistance as the cultural orientation of post-colonial writing opposed, interpolated and then transformed the canon of English Literature itself (Ashcroft et al 199).
\end{abstract}

While the Afrikaner may technically be an African (as "Afrikaner" means African in Dutch), his status is so as the result of the colonization of the Cape by the Dutch (the French and English came later as well). South Africa is a settler colony and thus is today as a "culture affected by the imperial process from the moment of colonization to the present day" (Ashcroft et al 2).

Chapter Two will provide a review of the literature concerning the debate about the future of Black South African writing. In Chapters Three, Four, Five, and Six, I will textually analyze the content of each novel. Chapter Seven will connect the findings from the previous chapters and summarize conclusions. Therefore, this thesis is an attempt to analyze and synthesize the content of several works, which are used as case studies to understand the society from which these texts were written 


\section{CHAPTER II}

\section{REVIEW OF LITERATURE}

My thesis will compare pre- and post-1994 Black South African novels that feature the Black township as its setting. As previously stated, I will analyze the texts to figure how the writings have changed, if they have at all, after the formal ending of Apartheid. There is much debate surrounding my topic as literary scholars try to figure out what direction the medium should go or is going. There are two prevalent camps of scholars in this debate. There are researchers who feel that Black South African writing is crippled by its focus on Apartheid, and that if writers do not abandon their propensity for protest literature, South African writing will suffer. They feel that Black South African writers should begin to concern themselves with every day topics. The scholars on the other side of the debate feel that there is nothing wrong with Black South African literatures tradition of protest, and are not worried about finding inspiration in a post-1994 world.

Frantz Fanon (1965) constructs a progression for colonized intellectuals, writing when he discusses the process of decolonization into statehood. $\mathrm{He}$ 
argues that the colonized first write in the literary tradition of the imperial country due to the suppression of the natives' past culture. In the second phase, the colonized scholar realizes their identity in relation to their culture's traditional past, and in the final phase, the colonized scholar decides to fight back against the colonizer, producing literature that represents the realities of being colonized. The tradition of protest literature in South Africa suggests that Black South African writers are in the final stage. South African literary critic Barnett (1983) historical study on Black South African writing written in English suggests that it follows the path Fanon laid out. Barnett's comprehensive study examines how Black South African writing morphed from religious or Christian missionary writing to literature about historical events to finally the protest literature that South Africa is known for today.

Journalist James North's (1981) study of Apartheid literature describes how the Sharpeville Massacre enraged Black South Africans who then feverishly produced more literature protesting the system than they had ever done before. His article features, among other top South African writers at the time, Nadine Gordimer who expresses her discontent with how some Black South African writers are too politicized to do good writing. South African novelist and poet Christopher Hope (1985) also critiques Black South African writing, feeling that it is unadaptable to the changing political climate that the slow dismantling of Apartheid brings. His article, which studies political novels, argues that Black South African authors are unable to see the "dangerous ordinariness" of their oppressed condition. One famous criticism came from South Africa's 
Constitutional Court Justice Albert "Albie" Sachs, (1990) who argued that the literary solidarity politics would restrict the writing to being only about oppressors. He lamented that the literature had stereotypical characters and an overall lack of imagination. South African novelist André Brink (1993) also believes that as Apartheid reaches its end, literature is losing its creative steam. Writer Njabulo Ndeble (1994) argues that the oppression of Apartheid has made South African literature suffer from a lack of imagination, amongst other characteristics of fiction. He also argues that the literature is obsessed with politics and urban life.

After Apartheid has legally ended, scholars still feel that the excessively political nature of Black South African writing is having a negative effect on the writing being produced. An article featured in The Economist (1995) proclaims that South African writing is struggling to shed its political nature. The article quotes Brink as noting the "erosion of the imagination" of South African writers. The article critiques Black South African writers for writing only to mobilize people, for flat characters, with Whites playing villains and Blacks as heroes, and wonders when a new creative group will begin to write about different ideas that do not concern the past. South African writer Lewis Nkosi (1998) also criticizes Black South African literature for being resistant to recent movements in literature.

While many scholars find the protest literature tradition to be a problem other academics feel differently. Literary critique and writer Peter Nazareth (1974) argues that it has become the trend to say that South African writing is obsessed with Apartheid, but with Apartheid being a part of all life in South 
Africa, he feels it is appropriate. He does warn that this focus must be a shortlived one. A People's Voice author Piniel Shava (1989) also feels positively about the protest literature of Black South African writers and argues that as long as "the struggle" is in South Africa, the writers will always be protesting. South African literary critic Martin Trump's (1991) study argues that Black South African protest writing reflects the virtues and resilience of the Black community, and that it has always gestured towards socialism.

And, since the formal end of Apartheid, some scholars feel that South African literature has made appropriate changes in its approach and content. South African write and academic David Medalie's (1997) article disputes others attempts to try to stop Black South African writers from writing about the effects of Apartheid, which have not discontinued just because Apartheid is formally over, he argues. Thus, Medalie predicts that Black South African writers will continue to be concerned with issues of the past that persist in the present. He also believes that Black writers did not feed off Apartheid particularly, but that they were feeding off the community and life around them. Rachel Swarn's (2002) New York Times article applauds the new literature being produced by Black South African writers, suggesting, as Nazareth did many years before, that it is simple popular to critique South African literature for being dominated by protest. In addition, Dominic Thomas, a literary critic (2009) refutes the idea that Black South African writers are writing in a vacuum, arguing that their work is thoroughly engaged with the twenty-first century. 
The debate has attracted other researchers to study post-Apartheid literature. Ernest Cole's (2008) dissertation studies fiction from different phases in South African literature. He argues that a distinct post-Apartheid category has yet to manifest and that the current works since the 1980s represent interregnum and disillusionment. Literary critics Ronit Frenkel and Craig Mackenzie (2010) assert that literature since the ending of Apartheid can be conceptualized as "post-transnational," where the term transnational is defined as literature written after the 1990s, an era that the authors identify as a time of immense cultural and historical change in South Africa.

My thesis will add to this debate by analyzing the direction that some Black South African writers have gone with their works since 1994. This project is, therefore, extremely significant considering the legacy and significance of Black protest literature in South Africa. It will add specificity to the generalizations in the field, because I am looking at a very specific and under-researched topic. The area has not been given any focused attention, yet the communities the novels are portraying is one of the most important groups to study when it comes to understanding the environment of South Africa. This study will also analyze pre-1994 novels with the post-1994 novels using case studies. 


\section{CHAPTER III}

\section{DOWN SECOND AVENUE}

Ezekiel Mphahlele's autobiography Down Second Avenue was first published in 1959, after he went into exile in 1957. The books release coincides with a significant growth in Black South African literature at the time, which followed the Afrikaner Nationalist party's, the main proponents of Apartheid, rise to power (Shava 29).

The most noticeable theme is racism and racial prejudice, a prevalent theme in Black South African writing because, as Shava suggests, "[Racism] pervades virtually all aspects of South African life" (Shava 29). In the beginning of the text, Mphahlele is a young boy living in a small village with his grandmother, and he has little interest and knowledge of racism. But, when he is thirteen, he and his siblings move to Marabastad, a slum in Pretoria with their mother and father. He writes,

Marabastad wasn't fenced in as other locations outside Pretoria were. Nor were Bantule or Cape Location. So one could enter it from various directions. But the only White people we ever saw in Marabastad apart from the location superintendent, and the police, were a White minister of the Methodist church or a White priest of the Anglican church and a school-inspector who came and went 
surreptitiously... It never occurred to us that a White person could ever have cause to be in the location unless he was in charge of something or some people. I never even gave it a thought, and I don't think any other resident ever felt concerned about it (Mphahlele 23-24).

With this passage, Mphahlele describes the township setting as seemingly automatically suggesting Black inferiority based simply off the lack of and type of White interaction. Only seeing Whites in positions of authority creates the misassociation of all things authority with White people. When Blacks find other Blacks who dress or talk in a certain way or are very clean, they common response is "'They think they're White people' " (Mphahlele 53).

From here, Mphahlele's interaction with Whites escalates into events of predominately violence, humiliation, or both. One day when he is returning home from a White suburb where he had gone to pick up washing which his mother and grandmother did for White people to make money, he has an encounter with a group of White boys. Mphahlele writes,

I ran into the first boy in the row, who fell on to the next, and their row was disorganized...'Bastard!' shouted the boy who had fallen first. His friends came to me and about three of them each gave me a hard kick on my backside and thighs. And they cursed and cursed and then rode away, leaving me with the cold, the pain, the numbness, and a punctured and bent front wheel (Mphahlele 30).

His friend responds to his story by saying, "That's the first lesson, you've got to go about town with your eyes open" (Mphahlele 30). This is not simple, practical advice. Later, Mphahlele writes, "Get out of the White man's way! That is what most of us learned, and learned the hard way" (Mphahlele 90). The mentality was clearly to keep an eye out for Whites and to try to avoid them if possible. Mphahlele explains "There was enough hardship in my home without deliberately 
waiting to absorb the cruder impacts from our surroundings... The Black people conditioned themselves by the day, so as to survive" (Mphahlele 90, 93).

Another incident involves one of the days reserved for Blacks to go to the zoo, when a white couple realizes that the young Mphahlele and his friends can see them publically groping each other. Mphahlele writes,

“' 'Kick me a Kaffir tonight, Blikkies,' the girl said, looking murderously civil. I remember that during their little act our eyes met for a few seconds, hers and mine. 'Kick me a Kaffir tonight, my leif, won't you, my love? A nice kick on the arse of a nice Black Kaffir monkey, eh?' 'Tonight, my little heart? Why not now?' " (Mphahlele 91).

Mphahlele then describes how the man attempts to kick him and his other young friends and misses. Subsequently, they run away, and all Black people quietly flee that area of the zoo as well. Blacks were normally not allowed in the zoo, and on the rare days that they were, Whites could still invade their space at will and humiliate and terrorize them. The way in which even Blacks who were not involved in the incident desert the area is a great example of how Blacks were conditioned to stay out of the way of White people. This reaction is seemingly automatic, and even with the overt racist incidents described thus far, the author was still not conscious of the structural and pervasive racism around him. He does not question the condition that Blacks live in as compared to Whites nor does he ever connect racist incidence specifically with racism. He was content in believing, and thus letting, "The Whites do all the thinking" (Mphahlele 39).

It is only when he goes to St. Peter's Secondary School, a high school for non-White children, that he becomes conscious of racism. He states, "For the 
first time in my life, when I was at St. Peter's, an awareness was creeping into me; an awareness of the White man's ways and aims... Slowly I realized how I hated the White man outside the walls of St. Peter's" (Mphahlele 113-114). Mphahlele also states,

At first it was all a jumble of words to me when political debates went on. Gradually, as I listened, I was beginning to put into their proper places the scattered experiences of my life in Pretoria. Poverty; my mother's resignation; Aunt Dora's toughness; grandmother, whose ways bridged the past with the present, sticking to neither at any one time; police raids; the ten-to-ten curfew bell; encounters with Whites; humiliations (Mphahlele 115116).

His access to higher education is an essential vehicle for his consciousness.

Education plays an important role in Mphahlele's life from then on, however, before this point, he really doesn't understand the role that education plays socially. In the beginning of the book, when a young man is talking to the other village men about racism in the city, Mphahlele tells him "You read too much and believe too little" (Mphahlele 7). Here education is seen as negative and not socially valuable. For many characters in the book, education is seen only as economically useful. Even though the cost of sending him to St. Peter's was high and put a strain on the little money she had, Mphahlele's mother still agreed to let him go to school. She said, "'You'll come back and be able to look after yourself and the two you're leaving behind' " (Mphahlele 111). His mother did not send Mphahlele to school to become an activist against Apartheid; she obviously sent him there, because it was presumed that with more education, he 
would get a good job and be able to take care of himself and his siblings. It was an investment.

The main women in the text work tremendously hard to send their children to institutions of higher learning. Mphahlele's grandmother risks her already small amount of autonomy that she has to illegally brew and sell her own beer. With the money she earns from selling beer, she is able to get three of her sons higher education. Their neighbor, Ma-Lebona is also able to send her children to school. She states, "'Some foolish people think it is easy to get children through high school. You have to work, work, work, and stinge yourself of rice and stew, and wear rough German print" (Mphahlele 51). Later in the book, Mphahlele's grandmother repeats these same sentiments. She says, "You must starve yourself, stinge yourself rice and stew if you want your children to go to college, and some people don't know it" (Mphahlele 111). Education was seen as extremely important to these women, and the system of Apartheid, which created extreme economic inequality and limited Blacks access to knowledge, forced these women to starve themselves in order to get their children a good education.

When it comes to gender roles, women are the only ones in the text described as making such sacrifices for the education of the children; in fact, men are not discussed much at all and no male characters other than Mphahlele himself play major roles in the text. The familial role of men is never explicitly stated; what is clear is that men control the household and Mphahlele only describes this control as oppressive. His father is depicted as very abusive to his 
mother. During an argument, his father tells his mother, "Don't talk to me like that! Didn't your mother teach you never to answer back to your husband and lord?" (Mphahlele 15). It seems that the role of men in the household was simply to be in charge, regardless of if they were the main breadwinner in the household, which none of the main men in the text were. Mphahlele's mother takes care of him and his two siblings alone, and because of his father's violent nature and lack of interest in them, the children all hated him. I think that this negative relationship Mphahlele has with his father, who, after beating and subsequently hospitalizing Mphahlele's mother, disappears from his life, is the reason why there is a lack of men in the text. His grandfather dies before he is born, and besides from a few uncles who are mentioned sparsely, men are largely absent. The book itself is dedicated to his mother and the other women in his life.

The negative relationship Mphahlele has with his father is not the only reason why women seem to dominate the household and the text. This trend of women in control of Black households is a feature of Black families in townships. Josef Gugler describes how the process takes place. He states,

Typically, though, women in town wield increased control over the day-today affairs of the household. With the separation of workplace and home, most husbands are away for much of the day, leaving to their wives the running of the home and the education of the children. T he extreme case is the 'matrifocal' family. Marwick has suggested that with a few more generations of urban living the type of matrifocal family common among Negroes in diverse parts of the New World might be expected to emerge in South Africa as well, because their circumstances - particularly the determination of their social status by racial rather than economic and personal 
factors - are basically similar to those of Blacks in the Western Hemisphere (Gugler 298).

Gugler adds that Mphahlele's Down Second Avenue is an example of the matrifocal family unit in South Africa, which is a result of poverty and racism under the oppressive system of Apartheid causing tension between husbands and wives who live together as well as tension between husbands and wives who never see each other.

There is one important scene where men are present in Down Second Avenue; this scene takes place around the communal fire-place in the village when Mphahlele is a young boy. Mphahlele writes, "Men and boys of the village met here to talk important things and trifles, away from women and girls... We learned a great deal at the fire-place, even before we were aware of it: history, tradition and custom, code of behavior, communal responsibility, social living and so on" (Mphahlele 5). Women are only allowed to come near the fire-place to serve dinner, and it is seen as disgraceful for a man to have to stay at home "with women and girls" (Mphahlele 5). Mphahlele never explains whether the women have their own time of sharing such knowledge among themselves, and in this scene, the women serve the men who have separated themselves. The society of the village clearly has some patriarchal values; tension is created when these village values move to the town, where they conflict with the new economic freedoms women enjoy and where more freedom for a woman to work is necessary for the family to survive (Gugler 296). 
While men are only sparingly discussed, the role of women is very clear in the text. Mphahlele writes, "African women dare not look men in the face, let alone size them up" (Mphahlele 48). The one woman in the text who is described as being "bold" enough to look men in the face is Ma-Lebona. Even if Ma-Lebona is audacious enough to look at men in their eyes, she still understands the subservient role that women are to play. It is from her that the reader explicitly learns about the role of women. She says, "'A good wife must be obedient to her mother-in-law, she must be able to wash, clean, cook, clean the house and look after her children well...A young woman should go out and work or she must do washing to help her husband earn money"' (Mphahlele 48). Women's role was not strictly domestic; they were expected to take care of the house and the children as well as earn an income. With there being very few men in the text, most women are depicted as doing all of this without any help.

Black women are depicted in stark contrast to the White women who "work" in the offices that employ Mphahlele for menial jobs after being fired from his teaching position. Mphahlele states,

They seemed to do little more than let their bodies sway at their compressed dehydrated hips; perch like brittle china on their seats and paint their nails; pick up a mirror and adjust hair that didn't want adjusting and powder their bloodless faces; hold interminable conversations over the telephone and giggle in a sickening high tone that gave me the itch to hold their jaws open to get fullthroated laughter out of them...I wondered what manual work those White hands had ever done. Most likely none. There were Black domestic servants at their beck and call. Those red or pink nails, those thin lips that looked like the paper flowers we used to keep on our table in Marabastad (Mphahlele 162-163). 
Mphahlele seems particularly harsh on these typists, describing them as weak, superficial, and lazy; he even calls one woman a "dehydrated bosom." His severity in his description of them makes sense however when considering how dedicated the text is to its depiction Black women. The Black women in his life cannot afford such a "feminine" lifestyle. Mphahlele has to clean his family's home because his Grandmother and Aunt Dora were too busy washing White people's clothes that they did not have time to take care of their own homes (Mphahlele 44).

Black women are well aware of the contrast between themselves and White women, and also of their worth. After a neighborhood criminal named Blade rapes a Black girl, the community calls for justice. After he is bailed out, they gather outside of his home in protest. One of the protestors yell, "If he'd raped a White girl he'd have been locked up until he should hang"' (Mphahlele 81). After the criminal is only given a sentence of "ten years' hard labour [sic]," Mphahlele's grandmother says, "'You see, They hanged a man for doing what a White woman asked him to do in her own bed, and this is what they do to us!" (Mphahlele 81). Clearly, White womanhood was seen as something to protect by the government and was valued, whereas Black womanhood was not seen as valuable as that of White women. Mphahlele's portrayal of the Black woman experience makes the text not only anti-racist, but arguably a feminist work as well. The Black women in the text are "super-women," who take care of their homes, work, take care of their children, all the while facing hostility from Whites, an unjust system, and from Black men. 
Mphahlele's feelings about the Asian and Colored community develop throughout the text. When he was still a young man, he recognized that the Asians, particularly the Indians, were more privileged than the Blacks (Mphahlele 76). Even though the groups interacted with each other, he writes, "It seemed that we could never project ourselves into each other's lives and share certain things... I couldn't consciously probe into the attitudes of the Asiatics; I simply felt a barrier beyond a certain point of contact" (Mphahlele 76-77). While Mphahlele never overtly says that he feels the same barrier between Blacks and the Colored community, a distinct barrier of privilege and a mindset of superiority appear in the writing. Mphahlele recounts how the only house with a flower garden and a coal stove in the entire township belonged to a Black man who "boasted" a Colored wife; the family consisted of "a large brood of uppity children who were good at insulting their father because of his very dark complexion" (Mphahlele 22). The image of the light-colored children insulting their father is striking, and one must wonder if they felt themselves superior to their own father, they must have treated the rest of the dark-colored township with disdain as well.

Mphahlele also describes all of the Coloreds of Johannesburg as "uppity" (Mphahlele 116). In addition, he describes how his school friend Thomas, who had an African father and a Colored mother, uses his Colored surname for his examination, so that it will be the name on his certificate, rather than his real, African surname. Mphahlele states,

His reason was that if his certificate bore his real surname he wouldn't be allowed into the Coloured [sic] and Indian Normal College for teaching training. And he couldn't think of going to an 
African school because salaries were abominably low which was true. A Coloured [sic] and an Indian teacher did not need to have a university degree to get a nice plum teaching job. Those days he was paid four times as much as an African teacher with equivalent qualifications (Mphahlele 123).

Even though Mphahlele recognizes the privilege that goes along with the Colored identity and suggests that some Coloreds, particularly the Colored community of Johannesburg, can be "uppity," he eventually begins to view them, and his childhood, against what he calls "the bigger canvas of non-White suffering" (Mphahlele 143). Although he says that he as "no real bitterness against Indians and Coloureds [sic]," Mphahlele is very critical of their "group area politics" (Mphahlele 179). He writes,

How long, I asked, was the Indian merchant class going to dole out money to support their Congress only when a particular law was being resisted which threatened Indian business? Why had not the Indians ever helped Africans in their fight against, say, the Pass Laws, and only come in when Indian trade was being strangled by group area legislation? Did the Indian value parliamentary and municipal representation or did he just want to be financially safe? (Mphahlele 179).

His friend then admits that 'the average Colored was more concerned with 'keeping Coloured [sic]' (Mphahlele 179). The average Colored South African was more concerned with trying to keep the little privilege that they had; they did not want to be re-classified as "Native" or "Black." So clearly, from Mphahlele's viewpoint, there was a barrier between the Colored and Black population, a barrier of privilege and mindset, where many Coloreds were mostly concerned with how to not be classified as "Black" and how to keep the privileges that came along with their Colored status. 
The barriers between the Black population and other non-White groups are not the only tensions in the text; there is also a developing divide between tradition and modernity. Ma-Lebona gets very upset with her daughter and her new son-in-law because they chose to move into their own place instead of living with her. Ma-Lebona says, "'You know, Hibila [Mphahlele's grandmother], as old as I'm getting now, Black mothers and fathers don't make the same daughters as in the old days—when I was a girl. Those days we were told—not asked—told that the first baby must be born at your mother's" (Mphahlele 52). Mphahlele's grandmother also suggests that modern girls cannot cook (Mphahlele 48-49). Mphahlele's grandmother also expresses a fear of the modern medical technology of Whites. She states, " 'My mother used herbs on me and I used herbs on all of you and you must do the same on your little lambs. God has given the Black doctor wisdom which the White man hasn't got'" (Mphahlele 54). This could all be mistaken as simple and common griping from older generations if it were not for the patterns described earlier on in the book when Mphahlele is still living in the village. He writes:

The young able-bodied men were leaving the villages to seek work in answer to the call of the city. Vaguely I understood that Pretoria was the Mecca. At Christmas time they came back in dashing clothes: trousers with wide sweeping pipes, shoes with sharppointed front; hats with small brims; jackets with fish-tails, trying painfully but in vain to stretch beyond the hips in length; striped ties; belts with iron knobs and spikes worked into the leather; colourful [sic] handkerchiefs dangling boldly out of the trouser pocket. They told us about the glamour of the city life, the money ( $£ 3$ a month) and the electric lights and trams and motor-cars we had never seen before and had no hope of ever seeing until we were big enough to go to Pretoria...And there was a less glamorous side to all this. Wherever you went...you found mostly middle-aged women, old women and old men (Mphahlele 12). 
There is a pattern during this time period of young people fleeing the traditional life of villages and farming for the modernity of life in the cities.

The only people who resist the change are the non-Christians in the village, who are segregated from the Christians; religion offers another area of divisiveness. Mphahlele writes, "On one side of the river were Christian communities living together according to whether they were Methodists, Presbyterians, Dutch Reformists. On the other side there were tribal kraal communities. The Christians called them 'heathens' " (Mphahlele 4). Mphahlele goes on to describe how the Christians believed the non-Christian groups were "witches" and he was to not to walk on their footprints, to hold his breath when he passed them, and to simply not go among them because they were "addicted to whipping Christians" (Mphahlele 4). Although Christianity has seemingly yet to reach a consensus on "witchcraft," whether it is work of Satan or superstition, all of the rituals Mphahlele and the villagers do to not be tainted by the nonChristians seems purely superstitions and Mphahlele finds nothing but warm reception when he stumbles into their communal fire-places (Mphahlele 4). When discussing the non-Christians around the communal fire-place, the older men agree that they should be left alone, with Old Segone adding, "We all have our secret little gods, Christians or none" (Mphahlele 4).

This statement by Old Segone is telling; although the words "heathen" and "witch" spill out of the mouths of many of the Christian characters throughout the text to describe people they find doing things that they don't like, many of these 
same Christian characters also rely on the traditional religious belief of ancestors.

Mphahlele explains,

What I do know is that about eight out of every ten educated Africans, most of whom are professed Christians, still believe firmly in the spirits of their ancestors. We don't speak to one another about it among the educated. But when we seek moral guidance and inspiration and hope, somewhere in the recesses of our being, we grope around for some link with those spirits (Mphahlele 53).

There does not appear to be tension here; it appears to be an effortless as the coexistence of Christianity and indigenous religion. A good example of this comes after Ma-Lebona's son is left at the altar on his wedding day. Aunt Dora states, "'God knows best, but Joel was never meant for that sweet girl, and I could feel all was wrong when I dreamt of worms the night before the wedding, and when there was a halo round the moon, too'" (Mphahlele 56). In the same breadth, Aunt Dora expresses a belief and reassurance in God being omniscient, yet she also says a dream and "a halo round the moon" also is a sign of something bad ahead.

When it concerns religion and Apartheid, the blending is not as easy; Mphahlele, who joins the Anglican church as a young boy, becomes suddenly disillusioned with the Church as he becomes conscious of racism and oppression in his country. After he gets married, he and his wife move to a house near a township called Shanty Town, and "the squalor and poverty" he witnesses there reminds him of his old home on Second Avenue and awakens within him "spiritual conflicts" (Mphahlele 150). He writes,

I decided not to go to church any more. The White press, the White radio, the White Parliament, the White employers, the White church 
babbled their platitudes and their lies about 'Christian trusteeship,' the 'native emerging from primitive barbarism,' 'evangelizing the native,' 'White guardianship.' Secular institutions wrenched the pulpit from the Church cited the Scriptures, and the White man saw himself as an eternal missionary among non-Whites. The Church raised an occasional feeble voice of protest. The non-White had for years been taught to love his neighbour [sic] — the White man; the non-European preacher, the non-European congregations, had taken refuge in the hope of eternal life. While the White preachers, through sermons broadcast over the radio, told their contented suburban congregations the story of Calvary and individual salvation, White church-goers felt committed to group attitudes and the maintenance of a mythical White supremacy... Fellowship? Love? Obedience of the law? Suddenly I did not know what these meant in terms of my place in society, and I revolted against such preachments (Mphahlele 150-151).

The difference between what was being taught in the church and the reality of Apartheid eventually overwhelmed Mphahlele, and his fervor became stronger with time.

When Father Wardle comes to visit him about his lack of church attendance and his family owing church tithes, Mphahlele doesn't hold back. He states,

For years I have been told by White and Black preachers to love my neighbour [sic]; love him when there's a bunch of Whites who reckon they are Israelites come out of Egypt in obedience to God's order to come and civilize heathens; a bunch of Whites who feed on the symbolism of God's race venturing into the desert among the ungodly. For years now I have been thinking it was all right for me to feel spiritually strong after a church service. And now I find it is not the kind of strength that answers the demand of suffering humanity around me. It doesn't even seem to answer the longings of my own heart (Mphahlele 167).

For Mphahlele, religion was a key source in the promotion of the superiority complex that infected the minds of White South Africans, and also a key reason why Black South Africans had been so complacent in the system of Apartheid. 
Father Wardle later refused to baptize Mphahlele's third child, but Rebecca, Mphahlele's wife, insisted on "following the custom" even though she also felt disillusionment with the Church (Mphahlele 168). Mphahlele's distrust of the Church grows with time, and for him, it becomes the epitome of colonialism and Apartheid. In the Epilogue, he writes, "To [the African intellectual] the Church has become a symbol of the dishonesty of the West" (Mphahlele 210). This tension between the Church and religion and the reality of Apartheid is draped over the entire text, where religion is seemingly more important to many of the main characters, all the while they are treated with disdain and forced to live in desperate conditions.

If Black South African literature is indeed protest literature, the protests of Down Second Avenue come through perfectly clear. All of the major themes involve the immense strain Apartheid has on the ability of the characters to live their lives. The oppressive impacts of Apartheid racism and the terrorism people are subjected to leave them in fear, even within their own homes, which are already squeezed into the squalor of townships. The income inequality created by this racism has women unable to relish in femininity, having to work hard in order to get the children who show promise, into schools to receive decent educations. Different communities, which would benefit from unification, are at odds with each other, trying to hold onto whatever privilege that they have over one another. And through it all, the victims are made complacent by the Church, which collects their meager salaries and support Apartheid legislation. Mphahlele paints an ugly scene, and it is clear that Down Second Avenue was a protest he 
was offering the world, a glimpse into the country and the system to show that Apartheid was not just segregation of the races, but an entire system of daily crimes against humanity. 


\section{CHAPTER IV}

\section{THE MARABI DANCE}

Modikwe Dikobe's The Marabi Dance was published in 1973, a few decades after Ezekiel Mphahlele published Down Second Avenue. However, the literary climate had changed in the years between the works. When Down Second Avenue was published, Black South African writing was experiencing a "golden age." Activism and organized rebellion increased through the 1950s, leading up to the Sharpeville Massacre in 1960, in which police opened fire on a crowd of demonstrators protesting the pass laws that had restricted the movements of Black South Africans, killing sixty-nine people and injuring onehundred and eighty (Juang 987). Political opposition towards the Apartheid government had generally been non-violent, but after the Sharpeville Massacre, Black political organizations became more militant (Shava 51). Thus, the government made more arrests, and most writers went into exile, with their works banned by the government. Writers realized that they needed to "adopt a nonmilitant style" that would allow them to protest and while avoiding banning. 
Marks Dikobe Ramitloa was a well-known leader of the Alexandra Squatters movement, during which Black South Africans invaded and built communities on what was once "municipally-owned land" in protest of the conditions in the Black townships (Bonner "History from South Africa: alternative visions and practices" 64). Because of his involvement with this movement, Dikobe was "listed" and was banned from publishing under his own name, which is why The Marabi Dance is published under the name Modikwe Dikobe (Cornwell et al 84). Dikobe was born in Northern Transvaal and moved to Johannesburg at the age of ten, with his family eventually settling in the slums of Doornfontein. The Marabi Dance is set in Doornfontein during the 1930s. Dikobe also attended the Albert Street School like the novel's main character, Martha, and the book is dedicated to his classmates there. So, even though the book is a work of fiction, it is a work based on Dikobe's life experiences and was inspired by Down Second Avenue (Berger 110-111).

Even though it was inspired by Down Second Avenue, the short novel is noticeably different from Mphahlele's text, particularly in the way Dikobe writes about Apartheid and racism. There are no distinct moments of embarrassment and abuse between White and non-White South African characters in the novel. Just as the Black community in Down Second Avenue only sees White people in positions of authority, the White characters in The Marabi Dance appear only on the periphery of the main action and are usually in positions of authority. Martha's father, Mabongo, works at a dairy. Mabongo's boss, who he had known since the boss was a little boy, fires him. Previously, the loyalty Mabongo displayed 
towards him and his father had prompted the boss to promise Mabongo that he would never be out of work, but when Mabongo falls ill and misses a few days of work, he finds himself suddenly fired. Even after Mabongo pleads with him, reminding him of their long history and of the fact that it was Mabongo who taught his boss the family business, the boss still fires him, stating, "I want you to go and suffer a little bit' " (Dikobe 49). Even though this moment rightfully causes Mabongo great distress, the boss does not play the villain for long. Within a few pages, Dikobe settles the conflict caused by the boss's need to "put Mabongo in his place" when the boss comes to Mabongo's home to beg him to come back to work, offering more larger wages and guaranteed work for the rest of his life (Dikobe 58-59). The White characters in the novel generally follow this same pattern with none of them being completely cruel. While the boss's wife is busy removing Blacks from their homes in the slums as part of her social work with the Group Areas Act, she ensures that Martha will be able to get a new home with her rent paid for years, food, clothing, and a job at her new location (Dikobe 100). It is because of her that Martha does not end up homeless like so many others around her. Another example is the first time Martha visits Sephai at work. Sephai works for the McDonalds, and when Mrs. McDonald finds out that Sephai has a girl in his room, she rushes in the room and kicks Martha out of it, threatening to call the police, and leaving Sephai in tears. Once Mrs. McDonald realizes that she has interrupted Sephai's meeting with his prospective wife, she apologizes and gives him a day off to go see Martha (Dikobe 71). And this is the light in which White people are portrayed in the text during their interactions with 
non-White characters. They seem unconscious and aloof but when confronted with the reality that the Black people they interact with have complex lives and that these Black people are vital in supporting their standard of living, they become to some extent sympathetic to their conditions.

The best example of Dikobe's treatment of White characters in the novel happens after Reverend Ndlovu almost accidently hits a White porter while throwing his hands up out of frustration after being robbed. The White porter tries to offer advice on what Rev Ndlovu should do about his stolen money. The porter first suggests that Ndlovu should go to the police; Ndlovu responds to the porter by telling him that the police are the ones who robbed him. The porter tells Ndlovu that it probably was not the police that robbed him and that he should " 'watch out when people say they are the police.' " Ndlovu tells the porter that the police constantly harass Black people, asking to see their passes, and if the Black person questions the police, he can be thrown in jail for being "cheeky." The porter replies, "'You can explain to [the Magistrate] that you didn't believe they were police.' " Ndlovu states, " 'Ah! my friend, nice because you are a White man. White people believe other White people even when they tell lies and swear to God that they are telling the truth.' " The exchange continues with Ndlovu having to illustrate this point, and when he finishes, he states, "'You see, my friend, you are White and I am wrong.' " Even after Ndlovu makes his point, the White porter is unable to understand the full force of the oppression under which Ndlovu and Black South Africans live and how it affects their lives in ways that do not have to do simply with segregation. The porter simply apologizes for the 
robbery and accuses Ndlovu of sounding like an "agitator." The porter states, " 'You must not believe what these agitators tell you. They only want to get you into trouble. The White man is doing all he can for the Black man. You must be good to the baas and the baas will do all he can for you. You hear, my boy?' " Even though Ndlovu has explained just a fraction of the plight of Black people in the country, the White porter still does not seem to understand that "trouble" is already upon the Black South Africans, who are neither protected nor served by the justice system in the country. He also calls Ndlovu, who is significantly older than him, "'boy,' " revealing, if not a lack of respect, at least the habits of someone who was breed under a system that taught Black inferiority (Dikobe 2324). Dikobe's White characters in the text are simply unaware of Black life. They are sympathetic to the Black condition but to a very small extent and only in personal ways. They never become systemically aware. Accordingly, The Marabi Dance itself acts as a bridge for a White and/or Western readership that perhaps would not be able to understand the lives of Black South Africans otherwise.

Dikobe argues in the novel that the barrier between the Whites and Blacks in the text stems from the White characters inability to realize the humanity of Black people that they interact with, which is why only after being confronted with the different layers of their lives, do the White characters become somewhat considerate. While discussing White people, Mabongo's cousin states, " 'Perhaps when they know we are all people, they will learn to cook and wash for themselves and stop calling us boys and girls' " (Dikobe 40). The inability of Whites to realize that they "are made out of the same river mud" as Blacks 
creates the barrier present in the everyday interactions that Dikobe depicts (Dikobe 115).

While the interactions between the White and non-White characters were not volatile, the Black characters have many complaints about the Whites. After being fired, Mabongo grumbles, "You can't trust a White man" (Dikobe 49). The complaint that "White people have no respect" appears a couple of times in the text and comes from various characters. The Black characters not only feel that they are disrespected, but that Whites show a lack of religious respect as well. Mrs. Mabongo tells Mabongo's cousin, Ndala,

'I hate dairy work, for one has to work on Sundays as well. The dairy people want to make money on Sundays although the Bible says, 'Thou shalt work for six days and rest on the seventh day because the Lord thy God has worked for six days and rested on the seventh day.' White people have no respect for what the Bible says. It says 'respect thy mother and thy father' and yet they teach their children to call us boys and girls' (Dikobe 35).

Mrs. Mabongo is able to understand and express the differences between what the Bible says and the reality of Black South African life.

Dikobe discusses the topic of religion in a similar way to Mphahlele, in that his characters use the Bible to question and resist Apartheid. The same Bible verse is used in both texts as well. Reverend Ndlovu states, "The White Christians say, 'Love thy neighbour [sic] as thyself' and yet they don't love us' " (Dikobe 118). What the Bible says as compared to how White Christians act towards Blacks is a major source for protest against Apartheid because it is rife with hypocrisy. However, the similarity between Dikobe's discussion on religion and Mphahlele's ends here. The character Rev. Ndlovu wants to start a church 
for Africans since White pastors have churches just for Whites, and although the audience never gets the details about his "Church of Africa," if it mimicked the Whites-only churches that inspired it, it would be an African-only church and thus also be in opposition to the overall messages of equality in the New Testament of the Bible (Dikobe 118). There is also the imagery of the Black Moses speaking to people, which is apparently on a book cover that Rev. Ndlovu has and plans to show to people. Ndlovu plans on throwing the book with the White Moses away and plans on using the book with the Black Moses on the cover to inspire Black people to fight for freedom (Dikobe 17, 24). Why does it matter if Moses is Black or White? What should matter is the religious text itself and what it says not the appearance of who says it. It appears that Ndlovu will use the imagery of the Black Moses in the same way that White South Africans historically used images of the White Moses to feel superior to others. He is basically using the exact same strategy that was used against him to incite people to get the desired results that he wants, however well meaning those results are.

The reason I feel that Dikobe approaches religion and racism in this way is because his focus is on the Apartheid system as a whole and on how it has corrupted the people. Dikobe is not concerned with pointing out the hypocrisy between Apartheid and religion but rather how the said hypocrisy leads to more perversions of Christianity as clearly seen through Rev. Ndlovu who decides to start a African-exclusive church instead doing what he should be doing, which is emphasizing how race should not matter at all when it comes to religion. Ndlovu sermonizes, " 'Blessed are the meek for they shall see the kingdom of God.' My 
people are suffering. They own nothing on this Earth. This Bible is wrong to tell us we must be meek so that we shall enter the Kingdom of God' " (Dikobe 117). The scripture in the Bible is most commonly translated into meaning that people who are meek, like people who are poor or who are mourning, will be given special blessings from God. But, the verse has been taught under Apartheid in a way that promoted Black subservience to Whites. As a result, Ndlovu's understanding of the verse, which could be used to inspire his people to action, is distorted.

In addition, Dikobe is more worried about how the entire system of Apartheid breeds deceit, criminality, and other negative vices in its victims and not concerned with individual acts of racism. He leaves out portrayals of Whites as villains yet includes descriptions of Black characters reduced to treachery because of the Apartheid system. One of these characters is Ma-Ndlovu, whose husband abandons her in Zululand when she is three months pregnant. She goes to Johannesburg to find him. Once there, she learns how to make money by first working in the mines and selling beer and then by selling liquor, running Marabi dances (dance parties) and "Fah-fee" (a gambling game). When her estranged husband suddenly dies, Ma-Ndlovu appears as a grief stricken widow who wants the rights over her husband's body. However, it is later revealed that this is not the case at all. George's mother explains, "'Town people make money from dead bodies. They keep the bodies for longer than a week in order to get more people to collect money from' " (Dikobe 8). So, alongside running Marabi dances, which were seen as immoral by the community at large despite their 
popularity, and gambling games and illicitly selling alcohol, Ma-Ndlovu plans to make money off of her estranged, dead husband. All of the people coming to the nightly vigils, as part of burial rites, that Ma-Ndlovu holds are being swindled. Shava explains, "When Ma-Ndlovu first appears in Johannesburg, she is depicted as a character which evokes sympathy, a woman who has been deserted and cheated by her husband, Madonda. The need to survive in a harsh environment, however, teaches her a sad and callous lesson" (Shava 20). The environment drove Ma-Ndlovu to corruption, and The Marabi Dance repeatedly depicts how the Apartheid system breeds dysfunction because it creates few other options. From here, the money is re-stolen by Rev. Ndlovu and then stolen again by swindlers pretending to be the police. The Apartheid system creates an environment, which characters must take whatever opportunities are available to them in order to gain funds.

The exchange of daughters for cattle and other forms of wealth has been a part of the African tradition for hundreds of years; however, the economic crisis created by Apartheid has made it a necessity for Martha's family to marry her off to her cousin who has many cattle. When Martha tells her mother that she does not want to marry a boy from the country, her mother replies, "'Mehlolo! Do you think I have given birth to you for nothing?' " (Dikobe 28). Martha's family is Christian, but her family wants her to marry in her father's tradition. Martha's mother states, "'Lobola marriage is better because you get something for your child' " (Dikobe 87). Martha's cousin has a lot of cattle, and thus the bogadi, or bride price, is repeatedly mentioned by Martha's parents, who live in squalid 
conditions. Even when Martha's music teacher sends a letter saying that he wants to talk to Martha's parents, her mother only thinks that it is about marriage and says, "I shall tell him to pay magadi immediately' " (Dikobe 26). "Magadi" is another word for bride price.

But, Martha's teacher does not want to talk about marrying Martha; he wants to talk about Martha taking free singing lessons since she is no longer in school. In the very beginning of the novel, the audience learns that Martha has been taken out of school. Dikobe writes, "She sat for Standard Five, then her parents withdrew her from school because she'd been going out with boys, and they considered the fees to be a waste of money" (Dikobe 1). Just as in Down Second Avenue, education is viewed as very important by the characters. However, in Mphahlele's text, the audience is only exposed to the success stories of Mphahlele and girls like Rebone, who get higher education; in The Marabi Dance, the audience gets to learn what may happen to girls who are not as successful in school or who are viewed as engaging in risky behavior, like Martha. Education is still viewed as an investment, but in The Marabi Dance, it is an investment that parents can pull out of if they think the child is no longer worth the investment. Martha's mother tells her, "It is not going to be long before you are ready to have a child. We are wasting our money sending you to school" (Dikobe 10). While Martha is preparing for school, her mother asks her grandmother to physically examine her to "find out if she has slept with boys" (Dikobe 10). After they find out that she has indeed been having sex, her parents decide to stop her schooling. Suddenly, Martha is kept from all the 
consciousness and economic opportunities that education provides Mphahlele in Down Second Avenue.

Martha tells George, the boy she is having sex with, "I have lost my education through you and I have also had an unpleasant examination" (Dikobe 11). Martha's statement that she lost her education because of George is rife with the contention that is displayed between the sexes throughout the text. The woman that lets Ma-Ndlovu stay with her says, "Umadoda ezi nja - men are dogs" (Dikobe 4). Martha's mother tells her, "My child, men are selfish, they want to be treated like children" (Dikobe 11). The men are not above these same kinds of statements. A man tells Mabongo, "[Women] are witches" (Dikobe 45). It seems as if the sexes are in opposition with one another, and this set-up is clear in Martha's statement to George, where boys have the ability to stifle one's mental and economic growth. George sees Martha in the same light. When she gets pregnant, he says to himself, "She says she is spoiled and that girl is not pap like other girls I have spoiled. She is going to get me into trouble" (Dikobe 83). He pins the "trouble" on Martha and not on himself, and also that she is not like pap, soft, doughy-like porridge staple food of the Bantu peoples of South Africa. While Martha's "unpleasant examination" seems cruel and invasive, the invasion of Martha's body by her grandmother was a part of family planning; the examination determines if the family will continue to invest in Martha's education. Ancestors also invade Martha's spiritual body in the text to guide her.

Even though the family unit is working in its best interest, the poverty of Apartheid has mutated the way the family works; it has made Martha's education 
not a worthwhile investment since she is seeing boys. Also, Apartheid has caused the family to look at birth differently than African families traditionally would. Dikobe writes, "Africans look upon the birth of a child as a blessing. It is regarded as an asset to the family: 'I have borne myself a man. He will kill my enemies and he will work for me.' It is a general saying for Africans to express their gratitude for the new-born in this manner" (Dikobe 99). Yet, this is not how Martha's family views her or the prospects of her having a baby under Apartheid. When Martha tells her mom that she does not want to marry her cousin, her mother says, "'I wish God had denied me children. Women who have no children are better off' " (Dikobe 28). The way to gain economic mobility has changed and has made the African tradition of having lots of children to help the parents with work now counterproductive. Martha's mother tells her, "'You see that your father is not a healthy person. If he dies and you have a child there will be nobody to pay rent and buy food" (Dikobe 10). The traditional way of viewing children as a blessing is not $\backslash$ the best thing for the family, and would not be the best thing for most families who do not own their own land. With education being the best assurance for economic upward mobility, a new child can be viewed as more of a burden than a blessing.

Since Martha has been having sex, she will not gain access to the economic mobility that Mphahlele experienced, and immediately, the day after she is pulled out of school, she begins training to become "a woman." Her family sees marrying off Martha as the best way the family can gain a level of economic 
stability. It is from Martha's lessons on how to be a woman that gender roles are outlined. Martha's mother says,

'Moipone! you are today a woman. You must behave like a woman. Women do not hang about on the street corners at night. They prepare meals for their men. You must wear long dresses over the knees. Your father has given me money to buy you cloth for dresses and I don't want to see you sitting around the fire outside in the evenings. Women don't sit outside round fires like children. When they are not married, they help their parents by washing clothes or selling beer. A girl who does not behave like a woman never gets married, and if she neglects her duties, she loses her man' (Dikobe 11).

Now that Martha's family has stopped investing in her education, they begin to invest in her becoming a "woman", buying her new clothes to make her look like how they think a woman looks. Martha is also given many rules to follow that are meant to separate her from other children even though she still is a child and would be with other children had she not been pulled out of school.

When Martha is accused of receiving letters from boys, her mother tells her that she will never be a woman (Dikobe 25). When Martha comes home late, her mother tells her, "You shall never be a woman. Your children will fall into the fire. Ah! A woman who goes about at night fights with her husband every night' " (Dikobe 28). Martha also learns from her father that a woman is to make her husband's dinner, wash his feet, not talk back to him when he scolds her, and sexual intercourse, or "make blankets", with him whenever he wants (Dikobe 6366). If a woman refuses her husband sex, not only could she be forced to leave the home but he can also deny any children he has had with her. Husbands are 
not the only ones that can scold and humiliate a woman who does not know or

follow the so-called "home laws." Mabongo tells Martha,

'When you don't know these laws other women will laugh at you. They will take your man from you and make him happy and you will say he is a bad man and the women are baloi. The doctors will eat your money and say, 'We will make him come back'. You will wait many moons and will not sleep at night and you will become as thin as a stick of grass. Other men who loved you when you were still fat because your husband made you fat and beautiful, will not come to your house any more' (Dikobe 64-65).

Clearly, the rules a woman must follow are patriarchal, numerous, extremely strict, and are policed by the entire community. Mabongo's statement suggests that a woman's very happiness depends on how happy she makes her husband. How happy she keeps her husband is also representative of her worth and decides if she can take on the identity of a true woman.

Just like Mphahlele, Dikobe saw it fit to contrast the intense oppression that Black women go through with that of White women. When discussing colorblindness, or " 'no colour [sic] bar,' " Mabongo tells his cousin, Ndala,

'But Cousy, if they say 'no colour bar' and you marry a White woman, who will wash for you because White women can't cook or wash? They just sleep and say, 'Annie bring me tea, bring my petticoat and vest', and then they go out into the garden and tell a gardener, 'Boy! those flowers are no good, take them out. Go and water those flowers and when you have finished come and help the girl to wash the dishes' ' (Dikobe 40).

Ndala replies, "'I don't like them too. They are lazy' " (Dikobe 40). Because of their race, White women were allowed to escape the harsher aspects of patriarchal oppression that Black women had to contend with, and Dikobe 
suggests that they were did this at the expense of Black women, who fulfilled the traditional roles that White women would be expected to do in their homes.

Besides the fact that this discussion between Mabongo and Ndala shows how White women benefited from a less patriarchal oppression at the expense of Black women, it also shows how aloof Black men were to the sufferings of Black women. Even in their discussion about equality, they do not consider that they also bark similar orders to the women in their lives. They do not see themselves as benefiting from a patriarchal society. This discussion in the novel foreshadows the real life usage of the term "Rainbow Nation," a phrase that is meant to be a symbol of equality yet seemingly ignores all other forms of oppression, including that of sexism and homophobia, in order to emphasize racism.

The role of men in the text is never really clear or discussed. It appears that the role of men is to work and provide income for the family; however, as previously discussed, women were also asked to fulfill this same role. Even with the long list of things that a woman must do and the basically non-existent list of tasks a man must do in the home, Mabongo states, "'A house without a man is not a home' " (Dikobe 65). He seems to be completely oblivious to the fact that while he is at work all day, his wife is actually running the home.

Martha's mother and father try to teach her how to be a woman, their lessons should have focused specifically on motherhood; Martha becomes pregnant with George's baby before she is set to marry her cousin. After she tells 
the families about her pregnancy, her father rushes off to fight in World War II and her mother falls ill and dies. While Martha finds happiness after she gives birth to her son, Dikobe emphasizes the real burden of giving birth under Apartheid that Martha is either ignoring or unaware. Dikobe writes,

That night she entered into the life of motherhood. Sleepless nights with the child crying. Sick baby to the clinic. Tender love of motherhood. Battle to bring up a respectful child. Problem of giving it a good education. Its future in a country where a person is not judged according to his talent but by his colour, denied the right to take part in the administration of the country and the right to do skilled work. On this particular Saturday night Martha conceived a child who, among millions of others, was to spend his life in and out of jail...Martha, and many of her time, hoped that the law would treat them as human beings because they had attained a certain measure of civilization. It was not to be" (Dikobe 78-79).

Under Apartheid, the birth of a new child meant the birth of another Black person for the system to oppress and abuse. Dikobe also uses the same idea to describe Martha's mother's legacy after her death. He writes, "Ma-Mabongo died in the hospital a few days after being admitted. She died poor but she left a legacy for the White people-that her daughter remain a servant to them, a nanny, housekeeper, cook, even to the extent of opening and closing the gates for the master's car" (Dikobe 92). The cruel reality of birthing and the burden that mothers had to face under Apartheid was that their children would someday be treated as awfully as they were treated.

Another conflict created within the Black community, by the regime of Apartheid, is the theme of traditional South African customs in opposition to Western values. As previously mentioned earlier in the chapter, Ma-Ndlovu and Rev. Ndlovu come from the country to the town and become corrupt. There is 
also much discussion about the differences between country and city people.

When Martha's mother is hesitant to agree to her receiving free vocal lessons, Martha exclaims, "I won't keep quiet to see myself turned into a country girl who is forced to leave school early and work in the White people's kitchens!' " (Dikobe 27). Martha also often complains about "farm boys". She states, "I don't like farm boys. They work in the kitchens, take out night chamber pots for the White women and wash their bloomers' " (Dikobe 91). Martha also did not want her son to have her cousin's name Ndala, because she considered it to be " 'oldfashioned' ". She states, " 'Other boys would think he was a farm boy' " (Dikobe 99). Clearly, Martha has many ideas in her head about what people in the country do and how they work; her disdain for the type of work that country people do really does not make sense considering that she, like her mother, does washing for White people too.

Mabongo tried to warn his cousin about the differences between city girls and country boys. Mabongo tells Ndala and his wife,

'... am speaking of what happens to a girl who has grown up in the town and a young man who has grown up in the country. The town girls want furniture, fancy dresses, nice shoes. They dislike the rough work which is done by country women, and a country man does not understand the life of one who has to buy food, coal, wood, and pay for the roof which he has to keep over his family. He does not understand the life of the town man who has to work for the whole of his life without possessing anything: a house, goats, fowl or cattle. He must always be on the run to go and work. If he loses his work, his children will go without food and be chased out of the house. Moipone must understand that my cousin's son will not like to stay in town. He wants to see his cattle and when he has built up his first home he might like to take another wife' (Dikobe 38). 
Ndala sees for himself how different the two worlds are when Martha is already

pregnant. When a very pregnant Martha is singing and dancing, Ndala comments,

'My son would have been lost if he had married such a woman. She is pregnant but still moves about like a springbok. What can a farm boy do with a town girl? She would leave him with the children in the night and go to Marabi. I shall tell my child not to be sorry about not marrying her. She is only good for town boys' (Dikobe 97).

This difference in values and lifestyle creates a cultural barrier that goes beyond the spatial gap between the two worlds.

The theme of South African tradition versus Western culture also appears when Martha is performing at a concert hall and there happens to be a group of Zulus nearby performing a war dance. Dikobe writes

The contrast between the Western and the African dance was notable. The one, a shuffling of the feet, and the other, a vigorous stamping. The latter a dance of people witnessed by a large crowd and the other of dancers unwitnessed, men and women locked to each other. The free air swept away the perspiration of the Zulus. The closed air polluted the hall and when the music stopped there was coughing (Dikobe 73).

The meeting of the jazz-like Marabi music with the Zulu war dance suggests that in South Africa, there are many different cultures moving to their own beats. While the Zulus are stomping cool and "free" in the night, the people in the concert hall are shuffling and choking on the air. The Zulus' war song is called "Whiteman be damned," which also (Dikobe 75). The two cultures are not musically blending but clashing. 
Just as in Down Second Avenue, the city people are described in The Marabi Dance as being concerned with Western items and materialism, while the country people are described as hardworking, freer, and generally in a more positive light; however, Dikobe describes a very different perspective on Colored people than Mphahlele. In Down Second Avenue, many Coloreds thought themselves superior to the Blacks. Conversely, Dikobe does not depict Colored characters as feeling this way at all, probably due to the negative sentiment that other groups held towards them, feelings that had more than developed over the twenty years between the release of The Marabi Dance and Down Second Avenue. Ndala is ashamed to introduce Sephai as his son because he is light complexioned like his mother (Dikobe 68). In addition, the MacDonald family that Sephai works for "treats him with sympathy" because of his mixed race appearance. Mrs. MacDonald thinks "'He might be descendant of some of my family. God knows the sins of men' " (Dikobe 68). The suggestion that miscegenation was a sin bred the anti-miscegenation law that forbade the racial groups to have sexual relationships, but as an old woman recounts on the train to Martha, "Nature does not care for law' " (Dikobe 105).

While this is certainly true as far as miscegenation is concerned, Dikobe depicts the difficulty of being a product of miscegenation under Apartheid, where strict racial categories were determining factors in your entire life. Life takes on an extra level of complication for the Colored characters in The Marabi Dance. A great example of this can be seen in the only Colored character in the book other than Sephai, a gang leader named Black Cat. Black Cat, who the audience is 
told is the result of a relationship between an African and a Colored, could not finish a sentence in Sesuthu, his father's language, or Afrikaans, his mother's language. Instead of the languages perhaps blending, he just speaks broken pieces of both languages. He is not able to communicate fully in either language and thus is not able to completely be a part of either culture. This depiction of Coloreds as experiencing particularly difficulties with their identity differs from Mphahlele's depiction of Coloreds, and this shift may be due to changing attitudes in South Africa as the Apartheid situation gets more urgent and, like Mphahlele, Black South Africans realize the common struggle of all non-White groups. This progressive change in attitudes towards Coloreds may be more thoroughly in The Madonna of Excelsior, where miscegenation is a much more central theme.

In The Marabi Dance, the White villains and bad encounters are largely absent. Instead comes a direct critique of the Apartheid system and particularly Dikobe makes argument based on the economic situation of the Black community. The economic inequality and poverty has put a strain on not just what people could have, which sometimes reduced them to corruption, but also on their relationships with others, particularly within their own families, which had to adjust to other ways of upward economic mobility in order for the family unit to survive. Also clear in The Marabi Dance is the low status Black women have in the society, experiencing the double jeopardy of being both Black and women in a society that valued neither attributes. 


\section{CHAPTER V}

\section{THE MADONNA OF EXCELSIOR}

The Madonna of Excelsior was published in 2002, around seven years after the first democratic election in South Africa. Just like Mphahlele's autobiography Down Second Avenue and, to some extent, The Marabi Dance, The Madonna of Excelsior is a novel that is based on true events. The author, Zakes Mda, based the novel on the "Excelsior 19" trial in 1971, when thirteen women were charged with prostitution and six White men were charged with breaking the Immortality Act, a law which made intercourse between Whites and Blacks illegal (Wenzel 134). One of the characters, called the Trinity, is also based off of a real person. Mda vividly describes the paintings of Father Fran Claerhout throughout the novel.

The novel begins with the phrase "All these things flow from the sins of our mothers" and ends with the same phrase (Mda 3). Even though Mda begins and ends the novel this way, everything in between the beginning and end of the novel makes this phrase ironic and makes the audience question the definition of $\sin$. The main character of the novel, Niki, is tried for committing a sin; she has sex with a White man. 
It is through an analysis of Niki's life that gender roles can be analyzed. For the most part, women and men are expected to fulfill the same roles as previously seen in the pre-1994 texts. In the beginning of the novel, when Niki is young, she lives with her father who expects her to make his dinner even if he is too drunk to realize that he did not leave her any money to buy food. He even plans to beat her because of it (Mda 17). Niki's mother is dead from reasons that go unexplained. It appears that without a wife/mother around, the role of daughter becomes extremely important as she must take on the roles that her mother would usually have played. When Niki gets married to Pule, she is expected to keep the house clean, prepare food, take care of her child, and she also keeps a job at a butcher shop and works as a nanny for her employers, the Cronjes, at the butcher shop.

While women can be seen, once again, as having various responsibilities in the home, men's role is still the same, to financially support the family. Mda writes, "Most men came home [from the mines] only once a year. Those with a higher sense of responsibility came twice a year... Niki should just be happy that unlike many other men, Pule supported his family" (Mda 38). While men were supposed to support the family, they did not always do so. Even with the lack of daily household duties men had, they were still viewed as an important asset for a woman to have. Niki tells her daughter Popi, "'A woman needs a man in her life' " (Mda 250). Even though Pule is viewed as the ruler of the household, Niki has some say in his treatment of her. When Pule's jealousy gets out of control and he physically abuses Niki, she packs her things and her and their son Viliki 
move out and live with her relatives. After months of Pule's begging, Niki chooses to return (Mda 34).

While the gender roles are outlined in basically the same manner as the previous texts, rife with tension from the separation caused by Apartheid, which outlawed Blacks from skilled jobs thus forcing many men to work away from their families in the mines, Mda spends little time describing these roles and more time exploring the exploitation of Black women's bodies. Mda describes the society that appears to be completely obsessed with Black women's bodies. First, Niki's body is viewed as a playground and object of desire for Johannes Smit who attempts to rape Niki in a sunflower field. Mda blurs the lines a lot when it comes to the interactions between Johannes and Niki. Johannes and other White men secretly "play games" with the young Black girls in the community, who generally seem like willing participants, because the White men give them money and gifts. Niki is definitely unwilling the first time, but subsequent times that she finds herself underneath Johannes in the sunflower field, it is after much stalking on behalf of Johannes and willingness on Niki's own behalf to get some income. To be clear, though, this willingness is rooted in it being a reasonable option when compared to possibly starving or getting beat at home for not having food to cook; it was an avenue to bring in money under Apartheid poverty. Niki's friend Mmampe tells her "You can make a lot of money from this foolish White man. Just give him what he wants and eat the money" (Mda 19). Economic necessity makes this humiliation and assault an opportunity for economic gains for Black girls and women. Because Johannes ejaculates on her thighs, becoming limp 
before he can even penetrate her, her body becomes, what Mda calls, a "masturbation gadget" (Mda 20). This would not be the last time Niki's body would be used in such a way. Little Tjaart Cronje, the White boy Niki looks after, would ask to ride on Niki's back and play "horsey". Eventually Niki realizes that when Tjaart is on her back, Mda writes, "He induced erection and worked himself up with unseemly rhythmic movements" (Mda 110). After she realizes that Tjaart is humping her and using her as a masturbation gadget, she stops playing the game with him.

Of all the moments in the novel, the most influential on the plot is the humiliation Niki is subjected to when her boss thinks she has stolen some meat at work. Cornelia Cronje would weigh her employers when they came to work and when they left every day to make sure that no meat was stolen. When Niki, who, because she has been asked to work so hard, has taken a late lunch and stuffed herself with food because of her hunger, weighs an extra kilogram, Cornelia forces her to strip in front of everyone. Mda writes,

'Take them off, Niki,' insisted Madam Cornelia. 'Everything! You must be hiding it in your knickers.' No meat hiding in her bra. Only stained cotton-wool hiding in her knickers. She stood there like the day she was born. Except that when she was born, there was no shame in her. No hurt. No embarrassment... Here they were. Raping her with their eyes. 'Magtig Niki,' said Madam Cornelia, 'where did the kilo come from?' And she burst out laughing as if it was a big joke. Everyone giggled. Including Niki, But there was no laughter in her eyes. She put on her clothes and went tamely home (Mda 40).

Once again, Niki's body is at the center point of an issue. Her body holds "secrets." And the onlookers "rape" Niki with their eyes. From here, her body 
becomes a fixation for Tjaart who was still a child and his father Stephanus

Cronje. Mda writes,

Niki's triangular pubes loomed large in Tjaart Cronje's imagination. Threatening pleasures of the future. A sapling looking to the starless sky for a promise of rain. He knew already that it was the tradition of Afrikaner boys of the Free State platteland to go through devirgination rites by capturing and consuming the forbidden quarry that lurked beneath their nannies' pink overalls (Mda 41).

Apparently, Black women's bodies were used as sexual trial runs for the White boys they helped raise. Stephanus, Tjaart father, would also only ever see Niki as a sexual object from this point forward in the novel. Mda writes, "For Stephanus Cronje, Niki's pubes, with their short entangled hair, became the stuff of fantasies. From that day forward, he saw Niki only as body parts rather than as one whole person. He saw her as breasts, pubes, lips and buttocks" (Mda 41). He has not fallen in love with Niki; he objectifies her, and he only sees her as body parts that can quench his sexual desires. The humiliation Niki felt from this event would turn into an "ungodly grudge" that would get Niki into a lot of trouble later in the novel. This is another area where Mda blurs the lines between good and bad, and it displays how the story is less situation based. Mda seems to be making the argument that public memory tends to remember events as being very "neat," with players that are good and players that are bad. The characters make decisions instead of having most situations thrust upon them. He attempts to create a novel that does not romanticize and/or simplify the past. The characters have more agency in the novel than in the previous texts. The trouble that was to come is presented as being not just the sins of mothers, but rather 
about the wrong done to Niki by Cornelia. But, Mda does not completely let Niki, who plots revenge against Cornelia, off the hook either.

When Stephanus admits that he wants to have sex with Niki, Mda makes it clear that Niki's grudge against Cornelia inspires her decisions. Niki does not hesitate to sleep with "Madam Cornelia's husband." There's even a "partner swapping orgy" of many other inter-racial sexual relationships that Niki and Stephanus join, but they never swap. The many Colored babies that are being born around town create many whispers in the area and eventually, the authorities investigate and arrest all suspected to have taken part in the orgies. The case creates a national and international scandal and Black body parts are blamed. Mda writes,

It was the Golden Age of Immorality in the Free State. Immorality was a pastime. It had always been popular even before laws were enacted in Parliament to curb it. It became a pastime the very first day explorers' ships weighed anchor at the Cape Peninsula centuries ago, and saw the yellow body parts of Khoikhoi women. But what we were seeing during this Golden Age was like a plague. In various platteland towns Afrikaner magistrates were sitting at their benches, listening to salacious details, and concealing painful erections under their black magisterial gowns. Afrikaners prosecuting fellow Afrikaners with cannibalistic zeal. Afrikaners sending fellow Afrikaners to serve terms of imprisonment. All because of Black body parts (Mda 92).

The interest in and exploitation of Black body parts had a long history in South Africa, with such notable examples as Saartje Baartman, a Khoisan woman who was paraded around Europe as a side show attraction because of her body parts in the nineteenth century. Now, the entire government and the Afrikaner sense of community felt threatened by Black female body parts (Mda 101). 
Niki's body parts do not just threaten politics and Afrikaan culture, but also they threaten the Christian religion. Another man that was charged alongside Stephanus was Reverend François Bornman. He, who would later say, "Remember always to obey the authorities because their authority comes directly from God", would try to commit suicide after the charge of breaking the Immorality Act was filed against him (Mda 125). As he lay wounded in his bed from a gunshot wound to the eye, he would "confess". Mda writes, It was the work of the devil, he said. The devil had sent Black women to tempt him and to move him away from the path of righteousness. The devil had always used the Black female to tempt the Afrikaner. It was a battle that was raging within individual Afrikaner men. A battle between lust and loathing. A battle that the Afrikaner must win. The devil made the Afrikaner to covertly covet the Black woman while publicly detesting her. It was his fault that he had not been strong enough to resist temptation. The devil made him do it. The devil had weakened his heart, making it open to temptation (Mda 85).

Thus, Black females were portrayed by this highly respected White authority as tools of the devil. They are never viewed as people but as objects to be used and manipulated by someone else, a perspective that reflected what had already been taught in the Excelsior church by Rev. Bornman concerning Blacks.

A plaque outside Rev. Bornman's church read,

'In honour [sic] of God, this stone was laid by J.G. Strydom-the Lion of the North who was the Prime Minister of South Africa from 1954 to 1958 , and made certain that he did not make equal what God had not made equal. He confirmed to his people: As a Calvinist people we Afrikaners have, in accordance with our faith in the Word of God, developed a policy condemning all equality and mongrelisation [sic] between White and Black. God's Word teaches us, after all, that He willed into being separate nations, colours [sic] and languages. The house of God' (Mda 29-30). 
Mda describes a religion deeply intertwined with the ideals of Apartheid and White supremacy. People who had been to Rev. Bornman's church before are described as never stopping to look at the plaque outside when they entered; only new visitors read the plaque, meaning the congregation inside accepted the ideals written upon it as truth.

One of the most subtly approached yet unsettling moments in the novel happen when the Cronje's ask Niki to nanny for Tjaart after church. Instead of sitting inside her church, alongside its all-Black congregation in a dilapidated building, Niki has to stand outside of her bosses church, Rev. Bornman's church, and wait for Tjaart. Blacks are obviously not allowed to attend the church service, but Mda never explicitly says so, which is one of the devices of the narrator, whose choice of what to say and what to assume the reader can put together make it feel as if the audience is getting the knowledge of the town from one of the Black township citizens.

Because it's never explicitly stated that Niki and Viliki cannot go inside, the reader is left with this odd moment where Niki and Viliki are outside the gate of the nice, sandstone church that is "shaped like hands in prayer" listening to Bornman's sermon. Bornman preaches Corinthians I, Chapter 13:3. The verse states, "And though I bestow all my goods to feed the poor, and though I give my body to be burned, and have not charity, it profiteth me nothing" (Mda 30). Niki and Viliki are outside of the gate listening to the reverend sermonize about charity, which means love in Christian theology, to an all Afrikaner congregation who does not lover her enough to let her sit down and worship with them. Yet, 
Niki enjoys the sermon. Niki joins them in their praises of all the things considered proof of "God's amazing grace", but the things that are being praised are the same things that Niki, being Black, cannot even enjoy. Niki does not question how committed the Afrikaners are to Christianity as other characters in the pre-1994 texts do. Niki never seems to notice how peculiar the entire scene is. Later in the novel, Rev. Bornman, who preached about love, would indulge in forbidden Black body parts, fail at committing suicide after he is caught, and declare Niki and all Black women objects of the devil and threats to the White Christian community.

It is not just Whites who are obsessed with Black women's bodies; Black males are also concerned with them. When Niki fails to have dinner ready because she has been sexually assaulted by Johannes, Mda writes,

"[Her father] was fuming because she had not cooked any food. She tried to explain that she was not feeling well. And in any case, there was no food to cook because he had not left her any money. But he was not prepared to listen to any lame excuses. He was going to beat the laziness out of her. He was going to lash her buttocks with a belt until they were sour" (Mda 17).

Her father attempts to physically beat her body to get what he wants out of it. This scene also brings out a disturbing pattern. Just like at the butcher shop, when Niki is forced to strip, and just like in the justice system and Christian religion, Niki's body is automatically assumed to be guilty of some offense during the conflict.

Even a young Viliki objectifies his mother. It may seem normal for kids to be possessive over their parents, but Mda's depicts an unusual scene, with Viliki 
thinking that he's been trading his mom with Tjaart so that he can ride Tjaart's bike when he gets older. Since Tjaart has been literally riding his mother, Viliki sees her as interchangeable with riding Tjaart's bike. So, even to her own son, Niki is comparable with an object.

The only time Niki feels "whole" is when she has control and agency over her body parts. Niki felt "whole," after her encounters with Johannes, after having sex with her husband, Pule, a partner she chose to have sex with (Mda 23). Having sex with Stephanus made Niki feel powerful too, if only temporarily (Mda 49). And, having sex in Cornelia's bed was exclaimed to be "Niki's greatest triumph!" (Mda 52). Even though the choice is limited, anytime she gets to choose her partner and the way her body is used, she feels empowered.

However, with all the negative messages Black women were sent about their bodies in the text, it comes as no shock that Mda describes a community of Black women with negative ideas about their bodies. In the beginning of the novel, a young Niki is glowing from use of Super Rose skin lightening lotion, but after a view years, her skin looks sunburned. Mda writes,

Although hers was not burnt by the sun. It had been devoured by the chemicals that the Krok brothers put into their Super Rose skinlightening lotion. The Krok brothers were diminutive identical twins from Johannesburg who used huge doses of hydroquinone to turn Black South Africans into White South Africans. They were reaping the great rewards in the process, since millions of Blacks people had taken to their skin-lightening products like bees to nectar and pollen. Niki was no exception. For even quicker results, she had changed from regular Super Rose skin-lightener to Super Rose HeMan, specially brewed by the twins to lighten the tough skins of Black men. It was even stronger than American products such as Ambi Extra and Artra. Hydroquinone did lighten the skin. But only 
for a while. Then it fried it until it became discoloured [sic] and hard like the skin of an alligator. Niki's world was falling apart with her skin. It had caked and was beginning to crack. Fire was burning in her cheeks. She blamed it on her incarceration. Had she been at home, she would have applied more Super Rose He-Man to her face. Her skin was crying out for Super Rose He-Man (Mda 79).

Niki does not believe Susanna, another woman in the Excelsior 19, when she tells her that it is the skin-lightening cream that is making her skin crack.

Susanna's own skin had patches on it, and "she had read in some magazine about the ravages of hydroquinone and about the Krok twins, Abe and Solly, who were amassing untold fortunes as a result of Black women's "quest for Whiteness" (Mda 79). The negative body messages society sent the women in this community made them think negatively of their skin color. The Black women who attempted the "quest for Whiteness" are left with the battle scars on their faces. In addition, Mda emphasizes America's role in this phenomenon, supplying many of the products such as hair straighteners or relaxers and messages about beauty in magazines (Mda 224). The negative messages the women internalized made them think that light skin and straight hair were superior to their own.

This is perhaps the main reason why Niki's daughter Popi, who is Colored with blue eyes, light skin, and straight hair is a source of teasing, rude comments, and sideways glances in the community. Mda writes, "Very few things made her laugh. Yet she was the source of other people's laughter. When other children saw her in the street, they shouted, 'Boesman! Boesman!' And then they ran away laughing" (Mda 107). Boesman is the name the San people, an indigenous tribe in South Africa who usually have lighter complexions, prefer to be called. 
Now, Popi's body parts are an issue; she is teased because of her hair, eyes, and later, when she reaches maturity, her legs, which would grow hair on them "like a White woman." The bullying, which came from people of all ages, makes Popi hate the way she looks. Mda writes,

She was fourteen years old. And she hated the mirror. It exposed her to herself for what she really was. A boesman girl. A hotnot girl. Morwa towe! You bushman you! Or when the good neighbours [sic] wanted to be polite, a Coloured [sic] girl. She had broken quite a few mirrors in her time. A mirror was an intrusive invention. An invention that pried into the pain of her face. Yet she looked at her freckled face in the morning, at midday and at night. Every day. She prayed that her freckles would join up, so that she could look like other Black children of Mahlatswetsa Location (Mda 110-111).

Popi is a Colored person without a Colored community. While she is hating all the things about her that make her different from the other Black girls and women around her, they are subconsciously hating the things that make them different from Whites; while Popi wants to look like them, they attempt to look like her.

Mda writes,

After thirty years, [Popi] had still not learnt how to deal with her hair. Even as a young girl she had always regretted the fact that she could not do the things that other girls her age did with their hair. She could not use the trendy hair straighteners like Dark-andLovely and Sta-sof-fro-all the way from America-because her hair was already straight. She had watched with envy as other girls relaxed their hair by frying it with chemicals or with red-hot copper combs. She herself was deprived participation in that ritual as her hair did not need relaxing... She could not use extensions because her hair was already naturally extended. She had watched with envy as grease dripped down her friends' ears after a perm... She alone, among her friends, could flip her head like a White woman (Mda 224). 
Popi does not realize the "quest for Whiteness" that her friends are on nor does she realize that because she is Colored, she naturally has the attributes that they desperately seek.

Mda's portrayal of the hardship Popi endures serves as an interesting counter narrative to the other descriptions of the Colored people of South Africa. Mda writes, "Popi's withdrawal from the world of her age-mates had been an escape from their snide remarks. Even at school, she kept to herself. And when she did, they said she was too proud to mix with them because she was a misis-a White woman. But when she tried to socialise [sic] with them, they called her a morwa-a Colored girl. Jokingly, of course. But still it stung" (Mda 114). The way Popi is treated by her Black neighbors adds a new perspective on the relationship between Blacks and Coloreds. Mda portrays a Black community that is ashamed of the Coloreds among them and that practically terrorizes its Colored citizens. Even Popi views other Coloreds with contempt because they remind her that she herself is Colored and not "normal" (Mda 196). The White community of Excelsior viewed Coloreds like Popi as an inferior to them and also held them in contempt; for them, Popi only serves as a reminder of what happened in the past. They do not see her as belonging to their community; after all, the Black women were the one's sentenced to take care of the Colored children, not the White fathers (Mda 89).

Mda's portrayal of the White community continues his attempts at muddying the lines between good and evil, where sweeping generalizations about the White community being exclusively evil and nothing more cannot be 
made. There are villains such as Johannes, but there are nice and helpful White characters such as Lizette de Vries, who some Afrikaners viewed as a traitor for advocating for equality (Mda 166). One character who best represents the complication of dichotomizing good and evil is Tjaart. While the image of little Tjaart humping Niki's back is almost too disturbing to forget, Tjaart does give Niki and Popi cake when he's still young and Niki is waiting outside a dinner party to scavenge for food (Niki 11). However, Tjaart grows up to be a racist adult and a White supremacist who is not proud of having spent so much time around Niki and Viliki when he was a child. Politically, he is a member of the Afrikaner White Wing and while on the city council with Viliki and Popi, he wastes no time insulting them, his childhood friend and his half-sister and only sibling.

But, Mda makes it clear that something more lies behind Tjaart's sinister ways. One day, Tjaart runs into Niki and Popi in town. Mda writes, "They looked at each other. Quietly for some time. Softness crept into [Niki's] eyes. [Tjaart's] remained blank. But there was a little twitch of a smile on his lips" (Mda 176). The "twitch of a smile" is all that survived the long years of conservative, Afrikaner brainwashing that had occurred since the days Niki was his nanny. Mda makes it clear that Tjaart's "good Afrikaner" perspective was "shaped by Afrikaans newspapers and the Bible" (Mda 25). Tjaart becomes so obsessed with the values that he believes in that he becomes seriously and physically ill after Apartheid has ended. Former mayor of Excelsior Oom Gys Uys claims that he knows why Tjaart has come down with the mysterious illness. He states, "'We all know. Let's not pretend. We all know that we used these children to fight our 
wars. And then we discarded them. All of a sudden they find that they live in a new world in which they do not belong" (Mda 248). Tjaart and others like him were raised to believe in White superiority and were trained to defend the idea with their lives. They did not realize that the elders who preached this idea did not actually believe in it themselves but just wanted to benefit from the economic inequality the ideas perpetuated. As Gys Uys explains, people like him now have wealth and issues of equality do not affect them as much; they have been able to easily transition into the "New South Africa," but for their pawns, people like Tjaart, and other young pawns, the transition has not been easy (Mda 248). As Niki later comments, Tjaart's anger from seeing Apartheid end and seeing his elders seemingly adopt and promote the new order eats him up (Mda 254). Eventually, Tjaart makes peace with Popi on his sick bed, going even as far as to acknowledge her as his sister. Mda thus makes Tjaart a character which the audience can feel sympathy towards, having been clearly manipulated by the White Afrikaner elite.

Mda's attempts at blurring the lines between good and evil is the main point of the book and is a critique of the "post-Apartheid" world, a world Mda's describes as a place that has generally forgotten what actually happened under Apartheid. Adam de Vries, who acted as lawyer in the defense of the White men in the Excelsior 19 case, now claims that he questioned the Apartheid laws after that case, even though he still argues that the Black women were bribed to frame the White men. He also claims that he stayed in the pro-Apartheid National Party for twenty-five years after he realizes Apartheid is wrong "to change it from 
within" (Mda 214). He states, "People like de Klerk and I changed the National Party from within. That is why today the National Party is the party that brought about the new dispensation in South Africa" (Mda 214). To this allegation, Viliki, who actually did fight to end Apartheid, responds, "You know, Meneer, these days it is very difficult to find a White person who ever supported Apartheid" (Mda 214). Even though De Vries claims to have been against Apartheid, he still has the old "painful" South African flag hung on his wall in his office (Mda 210).

Perhaps the White characters try to insist they were never pro-Apartheid because they do not want to appear to be benefiting from the lack of changes that have taken place post-1994, which has kept them still in a position of exploiting the masses. An example of this lack of change can be found at the bank where the two lines, one slow line for Blacks and one fast line for Whites, has been replaced with just one line. The one line was supposed to represent the new "one" South Africa. Yet, the White customers, such as Tjaart, do not get into the one line. Instead, they just walk right to the teller "who would immediately stop serving the Black customer to attend to the White one" (Mda 147). The change that is supposed to be a part of a move towards equality, is only a cosmetic change. Since the economic situation of the Black population also stays the same, the Black population, who had been promised a New South Africa, becomes frustrated, particularly with Viliki who became the mayor of Excelsior after Apartheid ended. They oust him and Popi from the city council.

The Black community in the novel also suffers from the same amnesia that seems to be plaguing the White population; they forget that Viliki and Popi 
brought them electricity, street lights, and a library in their short time on the council (Mda 199). Mda also emphasizes that the Black community forgot the truth about the Excelsior case. For example, the Black population's perspective on the Colored population shifts after the ending of Apartheid; they no longer view the Black women as disgraceful. Mda's writes, "From the outrage of rape (that's what we called it in our post-Apartheid euphoria), our mothers gave birth to beautiful human beings" (Mda 225). Neither Popi nor the other Coloreds in their town are products of rape. It was not love necessarily either, not in Popi's case anyway, that brought about the births of the Coloreds in the community. It was layers and layers of decisions and desires. Yet, in the world that has become so polarized by good and evil and Black and White, the true story, the one that Mda tries to tell with The Madonna of Excelsior, does not fit in the national story. This is perhaps why Mda insists on describing the colorful paintings of Father Claerhout; Mda reveals the layers of color in the events which he depicts because others only view them in Black and White.

It is not just an amnesia concerning the colorful truths that Mda depicts the Black community as having undergone in the New South Africa. Many other things have changed. The Black citizens do not pay for services such as water and sewage. Viliki admits, " It is true that when we were fighting for freedom, we encouraged people not to pay for services. It was part of the war for freedom. But unfortunately the culture of non-payment set in. People got used to not paying. Now even though we are free, they refuse to pay' " (Mda 186). Because of the 
lack of payment, the local government is in debt. Viliki also laments about the lack of caring among the Black community as evidenced in their lawns. He says,

'Today people don't care. They are now free. Tall grass grows in front of their houses. They expect the government to come and clean their gardens for them. Why else did they fight for freedom if the government they elected will not remove the grass in front of their houses? People are free. They must enjoy their freedom. They must sit on their stoops all day long and the government must feed them. During the days of Apartheid, they used to go out and look for work. Now they are free. The government must feed them. If Mahlatswetsa Location is filthy, it is the fault of the government. The government must clean Mahlatswetsa Location. Is that what freedom means to us?' (Mda 244).

Viliki describes a community that is finally free to be lazy; the downside is this is not a time when they can afford to be lazy. All of Viliki's complaints are made in private as it is now too risky to criticize a Black person, no matter how corrupt, as "racial arrogance" had turned any criticism into racism from Whites and if the criticism came from a Black person, the critic was deemed a "sell-out" or "lackey of racists" (Mda 233). Thus, Mda argues that corruption among Black leaders, such as with the character Sekatle, is allowed to reign following the end of Apartheid. The rise of Sekatle as a prominent leader in the community after Apartheid ends is a part of the Apartheid amnesia that the community suffers from; they do not remember that Sekatle sold out the members of the resistance movement during the struggle against Apartheid.

With the introduction of AIDS into the storyline, which makes death commonplace in the community, the image Mda's paints of post-1994 South Africa is troubling and desperate. While Mda plays with the idea of color, his emphasis on the oppression of Black women largely combats the notion of a 
"Rainbow Nation," and overall, Mda seems to suggest that there is nothing necessarily "new" about the "New South Africa." The people in the community are corrupt. Before the Excelsior 19 case, Maria and Mmampe convince Niki to let Johannes humiliate her to get his money. Years later, after Apartheid has ended, the same two, having been hired by the corrupt Sekatle to work on the council, are taking the town's money saying that "the spout of the kettle is facing their direction" and that it is now "their turn to eat" (Mda 250). Mda uses the characters of Niki, Popi, and Viliki to argue that the only path to peace is to abandon politics and the pursuit of wealth. It is only after Niki, Popi, and Viliki do this that they find true happiness. The fact that Mda chooses to write about pre1994 life during the post-1994 era shows that Black South African authors still feel the need to revisit the incidents that happened under Apartheid. Mda's time frame, which spans from the 1960s to the 1990s, shows the connection between the past and present, rejecting the notion that the Apartheid world exists in a vacuum. 


\section{CHAPTER VI}

\section{AFTER TEARS}

Niq Mhlongo's After Tears, which was first published in 2007, has one key difference from the other novels. There are few, if any, White characters and there are certainly no main White characters. Whites are simply not a part of the world Mhlongo depicts. If there are any interactions between the Black characters and Whites, Bafana Kuzwayo, the main character and narrator, never sees it as important to mention. There is also no mentioned interaction between the main Black characters and other non-White groups. Upon picking Bafana up from the train station after his year at school has ended, Bafana's Uncle Nyawana states, " 'Look at you! the Mother City has bathed you. You have gained complexion by spending all that time with the ngamlas and dushis. Yeah, you look handsome, my laaitie. All the girls ekasi will be yours' " (Mhlongo 12). Uncle Nyawana implies that Bafana is "gaining complexion" which seems like a rather interesting way to tell someone they are getting more handsome given the "quest for Whiteness" Mda writes about in The Madonna of Excelsior. And, Uncle Nyawana equates Bafana's gain in handsomeness to him being around ngamlas, or Whites, and dushis, or Coloreds. The final implication of this statement is that Uncle Nyawana is suggesting that people who do not go off to college, who are 
ekasi, or in the township, do not spend much around Whites and Coloreds. Thus, Mhlongo's entire novel depicts a world that is isolated from other racial groups. Whites and Coloreds do not take part in this world, thus, the complex relationship between the racial groups is no longer center stage.

Uncle Nyawana's statement to Bafana at the train station also represents an issue of language in my analysis of this novel. I found the novel to be an enjoyable read, and because it was published so recently, some of the descriptive details reminded me so much of the South Africa that I studied in abroad in 2008. However, when it came time to synthesize the themes and ideas for this study, I had a lot of difficulty. I read what was happening but could not necessarily understand the culture and motivations behind some of the characters actions. And, all the themes seem to flow into each other in a way that was extremely difficult to break down. I felt and had the comprehension issues of someone eavesdropping on a conversation. Uncle Nyawana's statement represents an aspect of this issue because he uses the words "ngamlas," "dushis," and "ekasi." I had no idea what these words meant. They are Sesotho words; ekasi, which means "in the township," is not even a traditional Sesotho word but a shortened version of an Afrikaans word "lokasie", which meant "location". The word has been adopted along with other words to make up the Sesotho language and culture. Mhlongo's has many Sesotho words throughout the book, and without the Sesotho to English dictionary in the back of the book, an international reader would miss much of what is happening in the novel. Some words used in the novel were not listed in the dictionary. 
Mhlongo uses "selective lexical fidelity," a post-colonial writing technique that "leaves some words untranslated in the text" (Ashcroft et al 63). Postcolonial writers use selective lexical fidelity as a device to draw distinction between the culture that is being written about and the language the literature is being written in. Throughout After Tears, the untranslated words constantly reminded me that while I admire South African culture, I am an outsider who is reading the novel in English. The intended audience is not me. Mhlongo wants his conversation with his audience to happen away from the spotlight and of the international stage.

Mhlongo directly confronts the issue of language within the text. Bafana's mother does not like his new girlfriend. Mhlongo writes,

Mama did not approve of my relationship with her and she made it quite clear to me that she preferred Vee. According to Mama, Lerato was a snob. She hated the fact that Lerato spoke English with a nasal private-school accent as if she had no chest. 'As a respected lawyer, Bafana,' Mama said to me the day I introduced her to Lerato, 'you're supposed to be seen with someone with good manners, like Vee. That private-school child undermines our African way of life; I haven't once heard her speak Sesoto.' 'But you've just met her, Mama, how can you judge her? Besides, even the so-called Black intelligentsia speak English amongst themselves.' 'English, my balls! Who's going to preserve our culture if we don't speak our own language?' 'But the only Black people that are preserving their culture are those that find it difficult to rise about the yoke of poverty, Mama. They're the ones selling fruit and vegetables in spaza shops and chicken feet on the pavements.' 'But how does that link to speaking African languages?' 'You can't think big in African languages, Mama, and you can't move out of the township either. I don't want to be trapped in Soweto forever. You know, when I enter our family house in Chi I can smell the poverty inside.' 'Did they teach you this in your university?' she asked, clicking her tongue in disgust (Mhlongo 174-175). 
This passage brings attention to the issue of language and education and the stigmas against African languages. The view that colonial languages like English are a superior form of communication is exactly the idea that Mhlongo is combating with his use of un-translated words.

Because the novel is not written for an international audience but for the communities and other townships like it, I may have missed issues of culture and other significant items. However, I feel that Mhlongo's motif is very similar to the Apartheid novel The Marabi Dance; extreme poverty has pushed people to extreme corruption because it leaves people with very few options. Poverty is still a key issue facing the township community and now it is coupled with the post1994 rising cost-of-living. Because of the poverty, money stays on the people's minds. Uncle Nyawana calls the upcoming year, the year 2000, "the year of two gees," with a gee meaning a thousand dollars. In post-1994 South Africa, it is not the color of one's skin that decides his/her fate, but how much green is in one's pockets. Uncle Nyawana states, "'Money can really talk in this country, I've seen it' " (Mhlongo 44). The implication is, if you have no money, then you have practically no say in the circumstances that control your everyday life. Uncle Nyawana's friend who lives in a shack in the backyard of the family home, insists,

'If you're Black and you failed to get rich in the first year of our democracy, when Tata Mandela came to power, you must forget it, my bra. The gravy train has already passed you by and like me, you'll live in poverty until your beard turns grey. The bridge between the stinking rich and the poor has been demolished. That is the harsh reality of our democracy' (Mhlongo 15). 
Whatever opportunities were made immediately after the ending of Apartheid are now out of reach for people from this community in Mhlongo's eyes just as in The Madonna of Excelsior; people are finding that democracy does not mean a change in their living conditions.

Because of this, Mhlongo's depicts the people as being extremely upset at the government. They are described as being even more upset now than they were under Apartheid. When Zero tells Bafana about a meeting to rally people against a raise in the price of electricity, he states, "'Siriyasi, Advo, these capitalists have removed the cables. Ever since we voted for them they do not give a fuck about us any more...I've never seen people as angry with the government' " (Mhlongo 156). The people are extremely angry; a woman over a loudspeaker yells,

'We used to pay cheaper flat rates for water and electricity under Apartheid. Why do we have to have this expensive prepaid with a Black ANC government? Why are we, the poor people, discriminated against by our own government?... They are only interested in exchanging the riches of this country with White people... Their honeymoon is over!' (Mhlongo 157-158).

At first, it is hard to believe Mhlongo's description of people being angrier now about the income inequality in the country than they were under Apartheid, however, Paul Gilroy explains this phenomenon in his book Postcolonial Melancholia. He writes,

Without the crude injustices of racial slavery and colonial conquest to orient us, we are required to know even more comprehensively than in the past precisely what we are against and why. But, as far as the order of racialized differences is concerned, our political imaginations are inclined to falter or become blocked at the point of maximum defense solidarity. That is where we are certain of what 
we are against but cannot say what we are for with the same degree of clarity and conviction... However well-intentioned it may be, the compensatory commitment to absolute unanimity cannot succeed for long. The inevitable appearance of differences within the favored collective creates grave disappointment with any group's lack of spontaneous fellow feeling and mutual regard. Here the ideas of identity, "race," and ethnicity can be seen to have damaged us all over again by feeding expectations of being together that are impossibly high (Gilroy 54).

As a result of the high expectations built by the racial solidarity championed under Apartheid and the first elections in "the New South Africa", the people in Mhlongo's novel generally distrust the government. The government is accused of being a part of many schemes against the people. One of those schemes is the lottery. Zero explains, "The lotto is just a clever money-laundering scheme. It was designed by the rich Black politicians and now they are just helping each other to get rich with it... These politicians are all crooks. Just steal R20 from anyone inside the taxi and you'll spend fifteen to twenty years in prison with hard labour [sic], but let the politician steal twenty million rand of poor taxpayers' money and you'll see. They always get away with it... There is no justice' " (Mhlongo 130). Since the people feel that they cannot trust the government to fix the issues of poverty, they have resorted to schemes of their own to make it.

Uncle Nyawana calls these strategies and schemes, of varying degrees of legality and corruption, "the politics of the belly," a phrase coined by JeanFrancois Bayart in his analysis of comparative politics and historical sociology in sub-Saharan Africa (Mhlongo 61). In the book The State in Africa: The Politics of the Belly, Bayart argues that Africa has a distinctly African power and political system. Bayart defines the politics of the belly as a kind of hunt for spoils of 
wealth and power, which is a mode of governance that is specific to each postcolonial state through its historical, cultural, and political environment. Bayart uses the Africans use the term to 'eat' to describe corruption as one of the many supports for his argument. The Madonna of Excelsior also seems to support Bayart's analysis of this aspect of life in sub-Saharan Africa; Maria and Mmampe tell Niki that they "eat" because it is "their turn to eat" and that Viliki and Popi were "foolish not to eat when the spout of the kettle was facing in their direction" (Mda 250). The result of the politics of the belly that both Mda and Mhlongo describe, appears to be a South Africa where many use a variety of schemes to gain wealth and power.

There are so many money-making schemes going on in the book that it's hard to keep them all straight. Some schemes happen on a large scale and involve lots of money such as a scheme involving car accidents and towing cars. Zero states, "'The tow trucks employ the street kids to fiddle with the robots. After the accident they tow the cars away to their scrapyards and charge you big zak to get them back. If you fail to pay, they sell your car' " (Mhlongo 79). There is also the International Christian Pentecostal Mission Church, which Vimbai Mataruse, who is called Vee, says that she heard is involved in drug trafficking and also pretends to heal cripples, who are played by actors (Mhlongo 155).

There are many other schemes that happen on a smaller scale. Some people are tsotsis, or gangsters, and rob people; Bafana gets robbed walking down a side street (Mhlongo 144-146). Uncle Nyawana plans on suing the Transnet train company for negligence because he fell and his leg had to be 
amputated, however he fell as he was hoping out of a moving train while attempting to steal a woman's purse (Mhlongo 13, 30-31). His only witness to the alleged negligence is Pelepele, or PP, who is a "notorious carjacker in Soweto and [whose] name alone carried terror in the township" (Mhlongo 11). Also, the neighborhood priest's wife, ma-Mfundisi, runs the fah-fee, gambling numbers game (Mhlongo 41). In addition, Sis Zinhle is rumored to have married her doctor husband for money (Mhlongo 98). And, Vee, who is from Zimbabwe, offers to pay Bafana to marry her so that she will not get deported and will be able to continue to work in South Africa (Mhlongo 187).

People also abuse the assistance the government is trying to provide to make money. Uncle Nyawana uses his "monthly disability grant" that is supposed to be used on medication to buy alcohol and cigarettes (Mhlongo 94). Uncle Nyawana tells Bafana about another scheme that young girls have began to commit. He says, "'Since [the child welfare system] started, young girls want to have kids with any man. Then they claim the child grant from the Welfare Department as well as financial support from the father every month. Double payment, you see, Advo?' " (Mhlongo 92). Dilika also insists that he knows people who have unprotected sex in order to get HIV so that they can apply for a state grant (Mhlongo 102). It appears that the people in the township use any means necessary to get their hands on money.

Bafana's entire family is involved in a scam which began when Bafana's grandfather was a part of the city council. The home the family has been living in for decades does not really belong to them because Bafana's grandfather " 
'submitted false documents to the local housing council' " (Mhlongo 73). Uncle Nyawana believes that his father stole a lot of other homes too (Mhlongo 45). This same scam appears in Madonna of Excelsior. The extensiveness of the scams in the family are discovered when the real owner of the Bafana home, Mr. Sekoto, sees the ad Bafana's mother places in the paper to sell the home. Mr. Sekoto's lawyers find evidence of mass corruption. Bafana's mother is shocked to learn how her brothers really got their homes from the government. Her lawyer states, "'They paid about R1,000 each to two corrupt officials. In return, those corrupt officials scratched out the original owners' names and put your brothers on the list as beneficiaries. They were actually not on the original list' " (Mhlongo 73). Bafana is shocked as well by his family's lies; however, he fails to realize that he is also a part of the lies. His pregnant mother would not be selling the family home if Bafana was not lying to her about needing the money to pay law school fees in order to get his certificate. The truth is that he failed his final year and is unable to get his certificate; this lie is at the center of the storyline of the novel. His law certificate not only represents wealth but also power, and his family calls him "Advo" which is short for "Advocate." His law degree holds the power for him to change his community. His scheme mimics Bayart's description of the politics of the belly and the rush for wealth and power in sub-Saharan Africa. As Zero states, " 'We're all crooks here in Mzansi, man! Politicians, hawkers, businesspeople, government workers, police, traffic cops, lawyers, prostitutes, all of us... We're all crooks, including these successful young women. The majority of them fuck their way up the corridors of power' " (Mhlongo 127). 
All of the bribing and scheming generally makes people distrustful of one another. It seems that "the politics of the belly" has driven all in the community, and even outsiders such as Vee and Bafana, to corruption.

Uncle Nyawana's "politics of the belly" is on everyone's mind. When Uncle Nyawana dies, PP delivers chilling words at his funeral. PP states, " 'The death of my friend, bra Nyawana here, was a dream come true for him. I mean, he knew that one day he was going to die like most of us will of AIDS or hunger here ekasi' " (Mhlongo 193). This is a sobering statement and a testament to how much of an issue the AIDS virus has become in Black townships. AIDS is a key theme in After Tears. First, the disease is mentioned in one of Uncle Nyawana's many schemes to make money. He tells Bafana, "We'll buy a funeral parlour [sic] and make huge profits from the tenders we'll get from the Department of AIDS because people in Msawawa die of those worms every day' " (Mhlongo 14). The notion that many people within the community die every single day from AIDS adds more stress on the already desperate situation in the township.

Even though AIDS seems to be common, there is still much debate between the characters about certain aspects of the disease. PP argues, "'The best way of testing yourself for HIV is to get your girlfriend pregnant. If her brat comes out clean, then you know that you're okay as well' " (Mhlongo 104). PP's constant bragging about how many women he's slept with and his mis-education on the virus foreshadows his future fate. At the end of the novel, Bafana's sister Nina tells him that PP had "suddenly become very ill and bedridden" (Mhlongo 217). The rumor around the township was that he had AIDS. Another debate 
involves AIDS medication. Bafana's little cousin Yuri has AIDS, and when

Bafana's mother notices he is not doing well, she asks Sis Zinhle if she had given him his pills. To this, Uncle Nyawana insists, "I don't even want to see those pills because they're the ones that cause AIDS. They killed my sister, [Yuri's] mother, Thandi, two years ago after she had started to use them... Those things don't stop AIDS, and the politicians are just lying to us about them' " (Mhlongo 86). Once again, a person distrusts politicians and blames them for the community's issues.

Sis Zinhle defends the pills saying that the antiretroviral drugs never claimed to cure AIDS and that she feels that the drugs are keeping Yuri alive (Mhlongo 86). Then, Dilika argues that the cure for AIDS does exist but that it is not being given to Africans. He explains,

'The right medicine for AIDS is available, but it's not for sale here in Africa. Has anybody heard of anyone dying of AIDS in Europe or America? The death rate is very low that side of God's world because there is a cure, but here in Satan's Africa the medicine is not for sale because of scientists see a long-term profit in letting Africans die. These bastards developed the virus as a biological weapon against Africans, and that's why we won't make it. We will continue to die like flies!...AIDS is not longer a death sentence in most First World countries' (Mhlongo 88-89).

Dilika may be an unemployed, alcoholic teacher, but his argument holds just enough truth, the death rates in the West are significantly lower, to make the reader truly consider his point of view. Yet, in the context of the reality of the rest of Mhlongo's novel, his viewpoint is not surprising. Everyone in the community is described as having some kind of scheme and the people in the novel have gotten used to expecting any and everyone to try to con them. 
Even though people are dying from AIDS every day, the relationship between men and women seems sexually unhealthy. There are no distinct family units working together in After Tears. There are no marriages. In fact, when PP is talking to Sis Zinhle, jokingly insisting that he is going to marry her daughter, Uncle Nyawana says, "I think you guys must shut up about your lobola shit. What's the use of paying fifty pregnant cows just to marry one useless nagging cow?' " (Mhlongo 121). Uncle Nyawana's negative attitude towards marriage and women is echoed by many other male characters. Bafana's mother warns him about this. Bafana states,

'Mama had warned me that Zero and PP had one thing in common and that I should keep away from them as much as possible. She told me that they were notorious for undressing every member of the female species that they saw with their eyes. According to her, they lived in the over-sexualised [sic] township world. In Zero and PP's universe, Mama once told me, a man was a man according to the number of ladies he was dating' (Mhlongo 48).

This over-sexualized world can be seen in the way the men choose to talk about their penises. When Bafana and his pregnant mother go to visit her brother in jail, a couple of guards joke about " "how well Uncle Thulani had used his joystick on [Bafana's mother]' " (Mhlongo 111). The penis is often referred to as a joystick in the text by the male characters. PP states, " '...l've sent women to maternity wards all over Mzansi with my joystick... Yeah, I tell you, I've turned thousands of women's stomach muscles to jelly with this... I bet you I can destroy it in two hours with my weapon of mass destruction...' " (Mhlongo 101103). For PP and other men in the novel, sex is like a game and they seek to 
"destroy," or conquer, as many women as possible. Achille Mbembe describes this phenomenon in the post-colonial state when he writes,

Pride in possessing an active penis has to be dramatised [sic], with sexual rights over subordinates, the keeping of concubines, etc. The un-conditional subordination of women to the principle of male pleasure remains one of the pillars upholding the reproduction of the phallocratic system (Mbembe 9).

Even though Uncle Nyawana is divorced and shares a negative attitude about women, he advises Bafana to find a woman. He warns, "That's why most boys here in Chi are either gay or rape women and children. It's all because they're afraid to say the three words. Not 'HIV', but 'I love you' " (Mhlongo 93). It is unclear to me where this fear of love originates, however the trend of absent fathers can also be found in After Tears. Mhlongo writes, "I had never known my father, or my paternal grandfather, and I had long ago accepted the fact that I was the product of a man who didn't care that I existed and a woman who hid the truth from me all the time" (Mhlongo 32). Perhaps the lack of fathers and positive male role models has created generations who are not used to seeing males show love. Homosexuality is also discussed in the text. After Bafana tells his uncle that he is not interested in "easy girls," Uncle Nyawana replies, "'That's nonsense, Advo! Or have you changed into a moffie? I know that those universities in Cape Town teach people to be gay. All gay people come from the Mother City' " (Mhlongo 92). Homosexuals are viewed by Uncle Nyawana as something synonymous with education and something that is bred outside of the township. 
The men think many negative things about the character of women in the township. " 'Kasi girls' " were described as " 'easy as ABC' " because they were materialistic. Uncle Nyawana tries to teach Bafana how to " talk these girls out of their panties with ease' " (Mhlongo 56). Of course, the only relationship the male characters express wanting to have with these women is a sexual relationship. Equally, the Black women from outside the township are also described as not having a good chance at finding a man. Zero expresses some jealousy towards Black women, who he feels have gotten a better chance to get economic opportunities, however, after Apartheid ended, they have had to pay for these opportunities by not being able to find suitable husbands. Zero explains, "'You see what Tata Mandela and President Mbeki have done to us Black men? This crazy system of theirs means that young Black women drive expensive cars while we Black men still belong to the walking class' " (Mhlongo 126). When Zero sees a woman driving a nice car, he continues, "'She has such a sense of selfimportance. That's why most young Mzansi women today are UDFs. Unmarried. Divorced or Frustrated. I tell you, Advo, these women's chances of finding Mr. Right are almost nonexistent here in Mzansi' " (Mhlongo 126). Zero believes that successful Black women only talk to men making " 'twenty grand per month' " and once they become frustrated with their high standards, they join MADS, the Men Are Dogs Society, or ABC, Angry Black Chicks (Mhlongo 128). Although Zero's anger and jealousy is revealed, if his argument is true, it represents an issue for successful, Black women in South Africa. When the men are unemployed and concerned with using their penises as weapons, who, can they 
be expected to marry? The female characters in the text do not necessarily fully reflect any of these views in their actions however. And also, all of our descriptions of them and their actions come filtered through male characters' viewpoints and never from their own minds or mouths.

With all of these issues that are confronting the people in the township daily, it's no wonder that people were flocking to the International Christian Pentecostal Mission Church, which was "healing" cripples. People were still looking for their miracle. However, Bafana, Uncle Nyawana, and his friends do not see the point of religion. Priest Mthembu, whose wife runs fah-fee, comes over to get vegetables from Uncle Nyawana'a stand and promises to pay him back in a few days even though he tells them that he has taken his money out of the bank in case of a Y2K mishap. This upsets Uncle Nyawana. He states, " I'm not here in Chi to serve his God. I'm here to serve my stomach. It's the politics of the belly' " (Mhlongo 61). Uncle Nyawana suggests that the harsh economic conditions conflicted with service to God. His viewpoint makes sense when poverty and AIDS are seen wreaking havoc in the township. When Bafana's mother asks the family to pray for Yuri, who is feeling sicker than usual, Uncle Nyawana refuses, asking, " Why should I pray? I mean, God already knows all my problems and if He's willing to help let Him come forward...I have my pride. If He's willing to help, He knows where to find me, l'm not hiding like $\mathrm{He}$ is' " (Mhlongo 118). Uncle Nyawana is pointing out that people are starving and dying all around him, and God has not shown up to help yet, so how could prayer help now? Religion appears to be irrelevant in the lives of the people living and dying 
in this township, which is why the few times Priest Mthembu shows up, there's always a comedic undertone present because he does not seem to realize how irrelevant his prayers and messages are. One of these moments happens when Priest Mthembu comes to Bafana's law office after he's bought a fraudulent law certificate. Everyone wants Bafana to become an advocate and lawyer for the community; when he views Bafana's fraudulent certificate in the office, he says, " 'I think God has answered our prayers' " (Mhlongo 160). If God answered the townships prayers by having Bafana buy the fake certificate, then Priest Mthembu unconsciously is suggesting that God is also a schemer like everyone else. This moment represents one of the strengths of the novel; Mhlongo is able to create humorous moments in an otherwise desperate situation.

In After Tears, poverty and AIDS have turned the hopeful new democracy into a pessimistic place where people generally know how they will die. The economic inequality between the haves and have nots is no longer dependent on race, and with the racial implications gone, people are realizing that the people they voted for may not have their best interests at heart. This leads to mass corruption on all levels and a keen distrust of all people. Even men and women are suspicious of one another, a suspicion which the AIDS virus has helped to inflate. Another issue that arises for the first time in the texts is xenophobia; the unemployed are mad that immigrants come and take jobs, while foreigners in South Africa must worry about cops threatening to deport them unless they give bribes (Mhlongo 23, 78). Everything seems to be in chaos. Consequently, the book's title has a double meaning. "After tears" or "After tears beers" parties are 
a New South African phenomenon. They are raucous parties that happen after funerals in the townships and are mostly frowned upon by the elders, because they are not a part of traditional funeral rites. After tears have music, dance, and, most importantly, alcohol (Mager 74). Everyday life in South Africa is also an after tears party where the death of Apartheid is celebrated. In an interview, Mhlongo told the interviewer,

In a nutshell, After Tears simply means a kind of celebration of life after the burial of someone. It is a way of trying to forget the death. So, literally, the issues discussed center on life after apartheid. After the tears of Apartheid, what are the youths of South Africa doing? They are still unemployed, there is too much corruption going on. So all these elements are very much involved in the book (Umaisha 1).

Mhlongo seems to suggest that even Apartheid is "dead," South Africans are still experiencing its lingering effects. And, this can most closely be seen by Verwoerd, Uncle Nyawana's dog, which is named after the mastermind of Apartheid, Hendrick Verwoerd. In the novel, the dog hangs around eating the leftover bones that people toss him. and at the end of the novel, Bafana has a dream that the dog mauls him while everyone else stands around laughing.

I have come across laughter in all the texts in some form or another; usually, characters laugh at one another or give a chuckle to cover up some kind of awkwardness. However, After Tears is full of comedic moments and laughter that occasionally entertain and sometimes confuse the reader. The ending is one of the more unsettling laughs in the novel. It could simply be that instead of lamenting their distressing situation, the characters in the novel, out of resistance, laugh instead. However, given the relatively lax resistance to their 
reality displayed by the characters elsewhere in the text, this laughter cannot be banality placed in opposition to the forces in power and seen as an act of resistance as Mbembe suggests in On the Postcolony. Mbembe suggests that "people who laugh are only reading the signs left like rubbish in the wake of the commandement' (Mbembe 8). They laugh at untimely moments in the text, acknowledging the power of their oppressors and then they continue in a way that seems complicit with their oppressors' desires, not combative. The main focus of the novel is the politics of the belly and how it gives South Africans few options. 


\section{CHAPTER VII}

\section{CONCLUSION}

The novels selected for this thesis deal with the lives of Black South Africans in townships. Through these novels, I have studied how South African authors perceived township life under Apartheid compared with how they now perceive township life after Apartheid's formal ending to understand how the tradition of protest literature has thematically changed since Apartheid's ending. In my study of Apartheid literature, I used Ezekiel Mphahlele's Down Second Avenue and Modikwe Dikobe's The Marabi Dance. In my study of post-Apartheid literature, I analyzed Zakes Mda's The Madonna of Excelsior and Niq Mhlongo's After Tears. I examined the themes of racism, the relationship between Black and other non-White populations, gender roles, traditions, religion, and education. I analyzed each novel using the qualitative research method within a post-colonial theoretical framework.

I found that the theme of racism gradually changed from being the main focus to being almost a non-existent issue as I hypothesized. In Down Second Avenue, the abuse and humiliation caused by Apartheid is fully confronted and 
most White characters are villains in text. In The Marabi Dance, however, the distinct moments of terrorism are absent. White characters are portrayed as having generally disrespectful perspectives on Black people and with the inability to recognize the sameness between themselves and other racial groups; yet, they are not violent and on occasion, provide aid to the Black characters in need. In The Madonna of Excelsior, Mda's writes about many different kinds of White characters with varying degrees of racial prejudice and some whom are actually helpful to the cause of Blacks, but he also focuses on how racial prejudice was particularly placed on Black female bodies. Still, racism is not the central issue in the novel. Racism is not the central theme of After Tears either, as Whites are largely absent from the book; Mhlongo is more concerned with the issue of poverty. Mda states in an interview,

It was easier to write about the past; that is a fact. Because the past created ready-made stories. There was a very clear line of demarcation between good and evil, you see? Black was good; white was bad. Your conflict was there. There were no gray areas. We no longer have that. In this new situation, black is not necessarily good. There are many black culprits; there are many good white people. We have become normal. It's very painful to become normal (Swarns 2002).

Mda implies that now that Apartheid is over with, Black South African writers have finally faced what Hope called South Africa's ordinariness. So, the topic of racism seems to become less and less significant to Black South African writers writing about Black township life over time. In an interview, Mhlongo confirmed my results. He states,

'This is a great time to be a black writer in South Africa. Most black writers who wrote before democracy focused on politics, but now 
there are lots of things to write about -- the AIDS pandemic, poverty, crime, xenophobia, unemployment. My scope is not limited to apartheid because there are so many things happening in South Africa today' (Donadio 1).

Because Black writers do not have to talk about Apartheid, they choose to focus elsewhere. Mhlongo does not even mention racism. There are some things wrong with this statement. As my study shows, Apartheid Black writers discussed many different issues. Also, the continued influence of Apartheid is still an issue of post-1994 novels; the post-1994 Black authors are just choosing to focus less on the matter.

The relationship between Blacks and non-White groups is a theme that was treated differently by all the authors. Mphahlele portrays the Coloreds as uppity and comments on a barrier between Blacks and Asians. Dikobe takes a different approach, portraying Coloreds as not uppity but rather as a confused people who don't fit into Apartheid racial dichotomies. Dikobe also depicts a Black community that is ashamed of Coloreds and the intermixing between the races. This same shame is portrayed in The Madonna of Excelsior, where the Black community is ashamed of the Colored population and the mothers who created them. Blacks tease the main Colored character, Popi, who struggles with her identity throughout the novel. Mda also critiques the post-1994 world for forgetting the true story of the Colored community. In After Tears, the Colored community is absent from the Black township world in the text.

The authors of all of the texts portray many different aspects of the gender roles and relationships that they depict. I did not initially plan on spending this 
much time on gender politics; I didn't realize how pervasive a theme it would be. However, I found that the authors describe the Apartheid system as being rigged to rely on Black women's labor, which corresponds to the fact that Black women, initially, did not have to carry a pass under the pass laws until 1952 (Schmidt 1). In South African writer Zoe Wicomb's David's Story, David decides not to flesh out his female character and prefers to let her remain "a kind of scream somehow echoing through [the] story" (Wicomb 134). Wicomb's novel represents the ways in which women were taken out of the memory of the anti-Apartheid movement. In the novels analyzed in this thesis, however, the male authors take a deep look into the hardships in the lives of women; it is more like someone physically shaking one awake and asking for attention rather than an echoing scream in the background. Mphahlele dedicates his book to his mother and grandmother, both women who are depicted in the text as fulfilling all necessary roles in order to take care of the family. These roles are expounded upon by Dikobe, who practically lists all of the rules and duties women are required to fulfill in the home. Dikobe also goes a step further by analyzing the burden of having children, or having more exploitable labor for Whites, under the system Apartheid. Mda shows the obsession and abuse of Black women's bodies by the people around them. Mhlongo in After Tears shows a significant shift, with women who are finally breaking away from the burdens and double jeopardy oppression of the past, which has inadvertently, however, come at the expense of having meaningful relationships with men. Men's role throughout the novels stays the same; they are supposed to provide financially for their families. 
However, Down Second Avenue, The Madonna of Excelsior, and After Tears all feature an absence of fathers and admirable male figures. Men are often portrayed as either away working or as gangsters.

The issue of tradition versus modernization or Westernization appears in several of the texts as well as the authors who describe this theme morally judge the influence of the West and modernity. Mphahlele depicts the movement of villagers into the cities. By the time of The Marabi Dance, the materialism that is a small feature of this movement in Down Second Avenue, grows and looms over Dikobe's analysis of town people versus country people. Dikobe depicts villagers moving to cities and becoming corrupt. Because The Madonna of Excelsior takes place in a rural community, there is less focus on the issue of tradition and modernity. However, After Tears seems to pick up where The Marabi Dance left off, with the people, who still live in poverty, being extremely corrupt in the post-1994 world. The authors suggest a gradual descent in morality as more Blacks accept the ways of modernization and city life under poverty. However, this is not to suggest that the authors romanticize pre-colonial contact with Europeans. The authors resist this; both Mphahlele and Dikobe depict sexist practices in village life.

Religion is a key theme in all of the texts. In Down Second Avenue, Mphahlele views religion as a key part of the Apartheid system, and the audience sees him change from member of the congregation to being angry with the institutional church. Dikobe also depicts the church in the same manner, emphasizing the same hypocrisy between what the Bible says and how Whites 
are treating Blacks. Mda goes a step further by showing how religion was used to uphold Apartheid in Rev. Bornman's church. And, in After Tears, Mhlongo depicts a world which has been ravished by AIDS and poverty and where religion is no longer as relevant. Clearly, more and more people are beginning to realize how religion is used against the people to keep them complacent in their conditions. Black authors continued to critique the institution of religion after Apartheid ends.

Education plays a large role in Down Second Avenue, as it is indispensable to Mphahlele's path out of the township and the main way to gain economic mobility. In The Marabi Dance, education is continued to be seen as an investment for families. Yet, in The Madonna of Excelsior, education is not a theme at all. In After Tears, education is back to being seen as an investment, as Bafana's mother sells the family home to get Bafana his law school certificate. However, at the same time, many characters in the book, including Bafana's mother, display a keen mistrust of the educated. Universities are even said to turn their students into homosexuals.

I argue that the authors' representations of the Black South African township reveal several changes over time. As time progresses, racism becomes less of a problem in their eyes, which could give the phrase "The Rainbow Nation" some validity if, however, the authors did not still portray the Black township as a place which is still very much isolated. In addition, the oppression which Black women live under is extremely brutal, with them basically being abused by all others groups, including Black men. The gains that they are 
depicted as making in After Tears have not yet made significant changes in the disrespectful ways in which others view them. Everyone asks the Black woman to do everything, and rarely, it seems, does anyone applaud or value her efforts in the novels. Finally, the materialism that often comes with modernization has coupled with poverty to bring about mass corruption among the people of South Africa, from the government all the way down to the children.

Through their depiction of poverty, corruption, and sexism, the Black authors of post-1994 South African literature reflect all that is wrong with the "Rainbow Nation" title, a phrase that ignores all of the issues at the center of most the writings, and refutes it. South Africa does appear, however, to be bordering on becoming a "Rambo Nation."

In one respect, the class based struggle, and exploitation of it, has created lots of violence on the ground. In another respect, the post-1994 authors appear to be engaged in a discussion and arguing against the romanticization and revising of history, or "Rambo-ification", that has taken place in the public memory, as particularly noted by Mda in The Madonna of Excelsior, where he critiques the way the characters remember Apartheid. It seems that even though the South Africa the authors depict is incredibly complicated, the tradition of protest literature has been indeed able to combat both the Rainbow and Rambo Nation motifs. Black South African authors prove that they can stand on their own and do not need the White Afrikaner antagonist to create meaningful work. It could also be indicative of how little things have changed since Apartheid ended in South Africa for the Black people living in the countries slums. 
I believe that this ability of the authors to represent a more authentic South Africa is rooted in the literature's readership. Whereas during the Apartheid era, Black authors catered to an international audience who they wanted to learn about and help fight against Apartheid, post-1994's authors are writing to a South African community. Thus, the need to hide the issues away from the scrutiny of the other is not there. If the shift had not occurred, the work Black South African writers have produced since the end of Apartheid would be more romanticized in an attempt to hide from the scrutiny of the Western world. However, fortunately, this shift in intended audience has indeed happened. it will be interesting to see how Black South African literature will change as time goes on and its conversation begins to grown in its exclusion of the international audience. 


\section{REFERENCES}

Ashcroft, Bill, Gareth Griffiths, and Helen Tiffin. Theempire Writes Back: Theory and Practice in Post-colonial Literatures. London [u.a.: Routledge, 1991. Print.

Attridge, Derek, and Rosemary Jane Jolly. Writing South Africa: Literature, Apartheid, and Democracy 1970-1995. Cambridge [U.K: Cambridge UP, 1998. Print.

Barnett, Ursula A. A Vision of Order: A Study of Black South African Literature in English (1914-1980). London: S. Browne, 1983. Print.

Berger, Iris. "Modikwe Dikobe's The Marabi Dance." African Novels in the Classroom. By Margaret Jean. Hay. Boulder: Lynne Rienner, 2000. 10714. Print.

Boonzaier, John. The Rainbow: Reflections on Christian Life in a Pluralistic World. Nairobi: Paulines Publications Africa, 2006. Print.

Brink, André. "To Re-imagine Our History." The Weekly Mail and Guardian [Capetown] Sept. 1993: 1-2. Review of Books. Web.

Bayart, Jean-François. The State in Africa: The Politics of the Belly. Cambridge: Polity, 2009. Print. 
Cole, Ernest D. Post-apartheid and Its Representation: The Interregnum as Motif in Selected South African Novels. Diss. University of Connecticut, 2008. ProQuest, 2008. ProQuest Dissertations and Theses. Web. <http://proquest.umi.com.echo.louisville.edu/pqdweb?did=1529760371\&si $d=1 \& F m t=2 \&$ clientld=9580\&RQT $=309 \& V$ Name $=P Q D>$.

Cornwell, Gareth, Dirk Klopper, and Craig MacKenzie. The Columbia Guide to South African Literature in English since 1945. New York: Columbia UP, 2010. Print.

Dikobe, Modikwe. The Marabi Dance. London: Heinemann, 1973. Print.

Donadio, Rachel. "Post-Apartheid Fiction." The New York Times. The New York Times Company, 3 Dec. 2006. Web. <http://www.nytimes.com/2006/12/03/magazine/03novelists.html?pagewa nted $=$ all> .

Fanon, Frantz. The Wretched of the Earth. New York: Grove, 1965. Print.

Frenkel, Ronit, and Craig Mackenzie. "Conceptualize 'Post-Transitional' South African Literature in English." English Studies in Africa 53.1 (2010): 1+. Literature Online. Web. $<$ http://proquest.umi.com/pqdweb?did=0000002164001641\&Fmt=3\&cl ientld=43168\&RQT=309\&VName=PQD>.

Gilroy, Paul. Postcolonial Melancholia. New York: Columbia UP, 2005. Print. 
Guest, Greg, Natasha Mack, Kathleen MacQueen, and Cynthia Woodsong. Qualitative Research Methods a Data Collector's Field Guide. North Carolina: FLI, 2005. PDF.

Gugler, Joseph. "The Second Sex in Town." Canadian Journal of African Studies / Revue Canadienne Des Études Africaines 6.2 (1990): 289-301. JSTOR. Web. <http://www.jstor.org/stable/2636643?origin=JSTOR-pdf>.

Hope, Christopher. "The Political Novelist in South Africa." English in Africa 12.1 (1985): 41-46. JSTOR. Web. <http://www.jstor.org/stable/40238564>. Juang, Richard M., and Noelle Morrissette. Africa and the Americas: Culture, Politics, and History, Volume 1. ABC-CLIO, 2008. Print.

Mager, Anne. Beer, Sociability, and Masculinity in South Africa. Bloomington: Indiana UP, 2010. Print.

Mbembe, Achille. "Provisional Notes on the Postcolony." Africa: Joumal of the International African Institute 62.1 (1992): 3-37. JSTOR. Web. <http://www.jstor.org/stable/1160062>.

Mda, Zakes. The Madonna of Excelsior. New York: Farrar, Straus and Giroux, 2004. Print.

Medalie, David. Journal of Southern African Studies 23.3 (1997): $507-$ 14. JSTOR. Web. <http://www.jstor.org/stable/2637514>. Mhlongo, Nicholas. After Tears. Athens: Ohio UP, 2011. Print. Mphahlele, Ezekiel. Down Second Avenue. Garden City, NY: Anchor, 1971. Print. 
Nazareth, Peter. An African View of Literature. Evanston, IL: Northwestern UP, 1974. Print.

Ndebele, Njabulo S. South African Literature and Culture: Rediscovery of the Ordinary. Manchester: Manchester UP, 1994. Print.

"New South African Novels: Still Coloured by Apartheid." The Economist 16 Dec. 1995: 4-5. ABI/INFORM. Web.

<http://echo.louisville.edu/login?url=http://search.proquest.com/docview/2 24108815>.

Ngũgĩ, Wa Thiong'o. Writers in Politics: Essays. London: Heinemann Educational, 1981. Print.

Nkosi, Lewis. "Postmodernism and Black Writing in South Africa." Writing South Africa: Literature, Apartheid, and Democracy 1970-1995. By Derek Attridge and Rosemary Jolly. Cambridge [U.K: Cambridge UP, 1998. 7590. Print.

Nkosi, Lewis. The Transplanted Heart: Essays on South Africa. Benin City, Nigeria: Ethiope Pub., 1975. Print.

North, James. "Writers Against Apartheid." Boston Globe [Boston] 24 May 1981, Boston Globe Magazine sec. ProQuest Newsstand. Web. $<h t t p: / / e c h o . l o u i s v i l l e . e d u / l o g i n ? u r l=h t t p: / / s e a r c h . p r o q u e s t . c o m / d o c v i e w / 2$ 94099298>.

Sachs, Albert, Kok Ingrid De, and Karen Press. Spring Is Rebellious: Arguments about Cultural Freedom. Cape Town, South Africa: Buchu, 1990. Print. 
Schmidt, Elizabeth. "Now You Have Touched the Women!": African Women's Resistance to the Pass Laws in South Africa 1950-1960. University of Wisconsin-Madison, 1982. African National Congress: South Africa's National Liberation Movement. African National Congress. Web. $<$ http://www.anc.org.za/show.php?id=8851\&t=ES>.

Shava, Piniel. A People's Voice: Black South African Writing in the Twentieth Century. London: Zed, 1989. Print.

Swarns, Rachel L. "Beyond Black and White; South Africa's Black Writers Explore a Free Society's Tensions." New York Times [New York City] 24 Jan. 2002. New York Times. The New York Times Company. Web. <http://www.nytimes.com/2002/06/24/books/beyond-black-white-southafrica-s-black-writers-explore-free-society-stensions. html $?$ ref=rachellswarns\&pagewanted $=1>$.

Thomas, Dominic. "New Voices, Emerging Themes." Ed. Abiola Irele. The Cambridge Companion to the African Novel. Cambridge: Cambridge UP, 2009. Print.

Trump, Martin. Rendering Things Visible: Essays on South African Literary Culture. Athens: Ohio UP, 1991. Print.

Umaisha, Sumaila I., comp. "South African Writers Address New Challenges." New Nigerian Newspapers [Kaduna] 19 June 2010. EverythinLiterature. 7 July 2010. Web. <http://everythinliterature.blogspot.com/2010/07/southafrican-writers-address-new.html>. 
Wicomb, Zoë. David's Story. New York: Feminist at the City University of New York, 2001. Print. 


\section{CURRICULUM VITAE}

NAME: $\quad$ Danielle Arianna Gantt

ADDRESS: $\quad 1122$ Larchmont Avenue, Apt A, Louisville, KY. 40215

DATE OF BIRTH: Chattanooga, TN, November 5, 1986

EDUCATION: $\quad$ B.A., English

Vanderbilt University, Nashville, TN, 2005-09.

AWARDS: $\quad$ Graduate Assistantship, Department of Pan-African Studies. University of Louisville, KY.

Graduate Studies Ethnic Minority Assistantship, The School of Interdisciplinary and Graduate Studies.

University of Louisville, KY.

Gertrude Vanderbilt Scholarship Award.

Vanderbilt University, TN.

PUBLICATIONS

\section{SELECTED ARTICLES:}

"Finding Leadership Through Loss with Guatemalan Nobel Peace Prize Winner Rigoberta Menchu." Vanderbilt Hustler [Nashville] 11 Feb. 2008, 120th ed.: 1.

Print.

"Highlander Research and Education Center: Some Elders May Struggle to Trust Generation Q." Vanderbilt Hustler [Nashville] 25 Feb. 2008, 120th ed.: 1+. Print.

"Racist Confrontations in Africa." The Talented Tenth [Nashville] Oct. 2008: 1. Print.

ACADEMIC CONFERENCES/PRESENTATIONS:

2011 University of Louisville Saturday Academy, Louisville, Kentucky. "Perspectives on Africa."

2011 National Council for Black Studies $35^{\text {th }}$ Annual Conference (NCBS) Cincinnati, Ohio, "Canonical Black Literature: 'Segu' and the 'African Idea'." 
2011 University of Louisville Pan-African Studies Department, Louisville, Kentucky. "Canonical Black Literature: 'Segu' and the 'African Idea'."

STUDY ABROAD:

2011 University of the West Indies, Trinidad and Tobago.

2008 Universiteit Stellenbosch, Stellenbosch, South Africa. 